\title{
ABSTRACT \\ ELECTRIFICATION AS DEVELOPMENT FOR SUSTAINABLE LIVELIHOODS AT MT. KASIGAU, KENYA
}

by Christopher W. Myers

Geographic research at the intersection between development critiques and political ecology questions a potential disconnect between extra-local development initiatives and local livelihoods. Kenya, under its Vision 2030 for sustainable development, is expanding the national electric grid to many rural areas, potentially introducing electricity as a process and effect on local livelihoods. I assess the introduction of electricity to Mt. Kasigau, a rural area in southeast Kenya, focusing on how the development intervention is perceived and acted upon by local communities and individual residents. Working with community residents in three villages the research employed a mixed methods approach, including participatory GIS (PGIS) to map and analyze the electric grid, and semistructured interviews to gain local perspectives on the processes of community and household-level electrification. The study mapped eight electrical transformers, 164 connected buildings and 11,607 meters of power lines, indicating about $18 \%$ serviced area and 38-71\% service population among the three villages. Respondents highlight distinctions among availability, accessibility, and reliability for homes and in the community and distinctive contributions to diversification. Local perceptions on introduction of electricity are clearly positive at Mt. Kasigau and shows benefits to sustainable livelihoods. 
This Thesis titled

\section{ELECTRIFICATION AS DEVELOPMENT FOR SUSTAINABLE LIVELIHOODS AT MT. KASIGAU, KENYA}

by

Christopher W. Myers

has been approved for publication by

The College of Arts and Science

and

Department of Geography

Dr. Kimberly Medley

Dr. Ian Yeboah

Dr. John Maingi 


\section{Table of Contents}

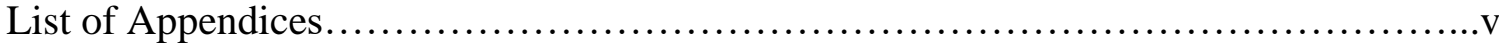

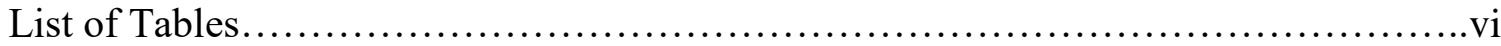

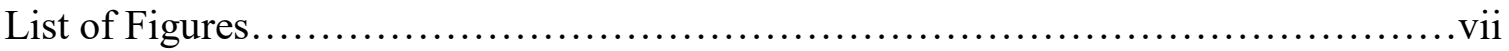

Acknowledgments.............................................................

CHAPTER ONE

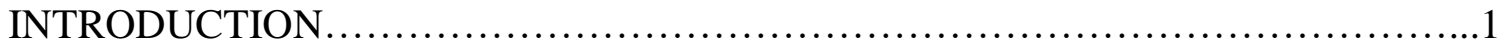

1.1 Statement of the Research Purpose and Questions...............................

1.2 Contribution to Research......................................................

CHAPTER TWO

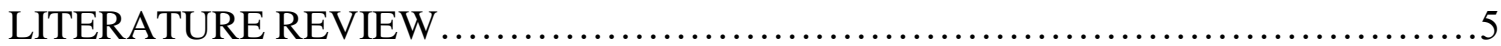

2.1 A Theoretical/Conceptual Context in Political Ecology .............................5

2.1.1 Sustainable Livelihoods Approach...................................

2.1.2 Development as an Extra-Local Effect.....................................9

2.1.3 Energy as Development.......................................... 12

2.2 Methodological Context - Participatory Methods to Validate Local Knowledge..13

2.2.1 Participatory GIS................................................... 13

2.2.2 Livelihood Analysis of Energy Use....................................15

2.2.3 Ethical Considerations for Participatory Research.......................16

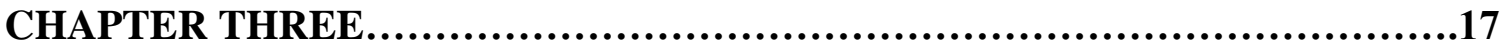

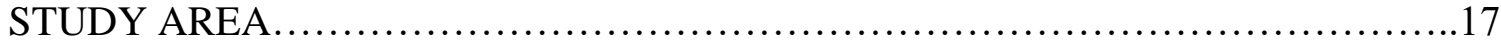

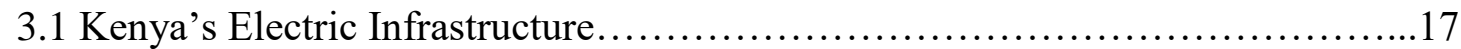

3.1.1. National Strategies for Rural Electrification.............................19

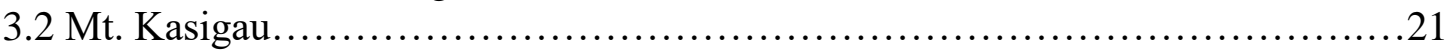

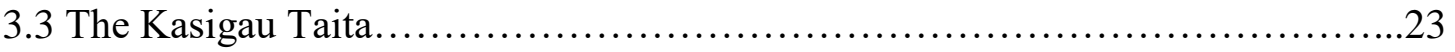

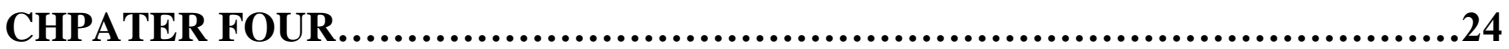

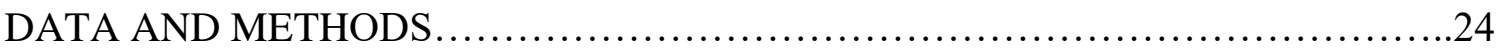

4.1 Participatory GIS Mapping of Electrification at Mt. Kasigau....................24

4.2 A Livelihood Analysis of Energy Use..........................................27

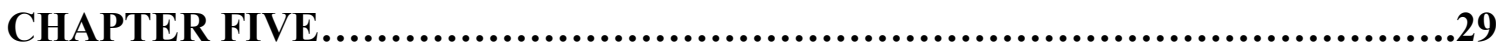

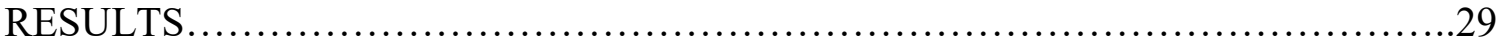

5.1 Spatial and Temporal Mapping of Community Electrification....................29

5.1.1 Electrical Connections for the Mt. Kasigau Study Region..................29

5.1.2 Comparison of Electrical Provisions among the Study Villages .............31

5.2 A Livelihood Analysis of Energy Use.......................................... 36

5.2 .1 Assessing energy needs.................................................

5.2.2 Community-level electric energy use ....................................39

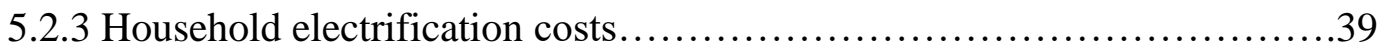

5.2 .4 Energy reliability ...................................................... 


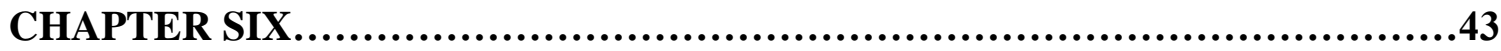

DISCUSSION AND CONCLUSION ............................................43

6.1 Electrical Development as Process and Outcome..............................43

6.1.1 Availability, accessibility and the use of electricity....................44

6.2 Electrification's Diversification Effect on Livelihoods..........................45

6.2 .1 Cost and reliability .............................................46

6.3 A Critique and Limitations of the Research.................................47

6.4 Conclusion......................................................... 48

REFERENCES.................................................................49 


\section{List of Tables}

Table 1: Electrical energy supply by source in Kenya, and demand breakdown in 2016 (Kenya National Bureau of Statistics [KNBS], Economic Survey 2017).................17

Table 2: A list of questions which guided the household interviews..................28

Table 3a: Comparison of total area to serviced area per village........................32

Table 3b: Estimation of total serviced population based on an estimated average

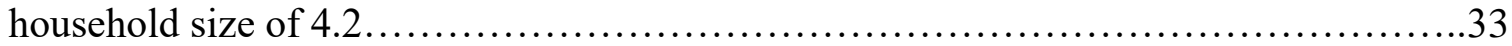

Table 4: Distribution of connected points at Mt. Kasigau, categorized by village and building type; Business (green); Living Place (blue) or Public Service (red) ..............33 


\section{List of Figures}

Figure 1: Conceptual model of the research framework.............................

Figure 2: Mt. Kasigau, Kenya, showing identified homes on the 2011 Worldview image

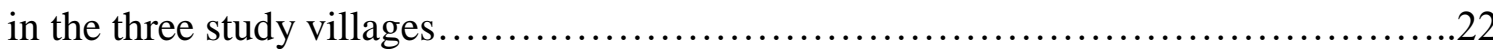

Figure 3: Participant mapping was conducted by members of the villages. Joseph Mwamodo assisted in instructing participants on how to use the GPS units. In the field, participants often took turns using the GPS units while we navigated the power lines, while the elder usually chose to walk in the front or back of the line. The 2011 WorldView image aided as a spatial reference to the groups while in the field.

Figure 4: A line ordering system that assigns a value to a power line based on the order in which it was connected from the main distribution line....

Figure 5: A narrative and photos which highlight the local constraints on the quality of the local infrastructure.................................................... 30

Figure 6: A map depicting the results of the participatory mapping exercises............31

Figure 7: A line ordering system, that assigns a value to a power line based on the order in which it was connected from the main distribution line. Note the greater infrastructure, more high order lines, in the Rukanga, where electricity was first introduced............35

Figure 8: Solar power being utilized in large and small capacities in the household, as well as at the community level for solar security lighting in Rukanga...................36

Figure 9: Electrical, solar and 'other' uses of energy described at Mt. Kasigau

Figure 10: Images highlighting the diversity of uses for electricity at Mt. Kasigau, including phone charging, welding, television and others

Figure 11: An illustrations of the relationship between cost and distance from the main power line reported at Mt. Kasigau. 


\section{List of Appendices}

Appendix I: Research protocol approved by the human subjects committee at Miami University..............................................................56

Appendix II: Letter of Consent supplied to participants..........................57 


\section{Acknowledgements}

First and foremost, I would like to acknowledge and thank my family, especially Mom and Dad, for all of your love and support throughout this process. To all, thank you for believing in me and for offering your encouragement and motivation along the way.

I would like to offer my sincerest gratitude to my adviser, Dr. Kim Medley, for guiding me through the processes of academic research and writing. Your passion and care for your students is inspiring, and your patience with me was enlightening - life is a collaborative process! I am very grateful for you guidance.

Thank you to Dr. Ian Yeboah and Dr. John Maingi for reading my thesis, and for offering constructive conceptual critiques along the way.

THANK YOU to the community of Mt. Kasigau, Kenya, for welcoming me to your home with open arms and allowing me to explore and learn about your ways of life. A special thanks to my friend and research assistant Joseph Mwamodo - thank you for your patience, dedication and hospitality.

To my fellow graduate student cohort - what a ride. Thank you for your support, motivation, critiques, humor and friendship. I don't know where I would have gotten my distractions from without you all! I am glad I was able to (sometimes) work alongside of you.

"To be free is not merely to cast off ones chains, but to live in a way that respects and enhances the freedom of others."

- Nelson Mandela 


\section{CHAPTER ONE}

\section{Introduction}

Political ecology represents a paradigm shift in how geographers are examining humanenvironment relations (Neumann, 2005). Extra-local (large-scale or "outside") influences need to be critically considered as process and response in relation to local adaptive strategies (Blaikie, 1985; Blaikie and Brookfield, 1987; Watts, 2015). Political ecology offers a critique of interactive human-resource relations that examines extra-local influences on local livelihoods. This "critique" may be recognized not in the traditional, judgmental sense of the word, but rather, as Rist (1997) points out, through the Kantian sense of 'free and public examination,' as political ecological discourse evolved (Blaikie, 2008; Robbins and Monroe-Bishop, 2008; Rocheleau, 2007). Research in political ecology, as practice, not only questions the historical complexities of how extra-local effects are introduced in communities but also how humans respond to these effects as factors influencing local livelihoods (Robbins, 2011; Watts, 2012). Development aid operating at international/national/local levels form a complex but significant extra-local process and effect that intersects with conceptual and applied critique in political ecology (Willis, 2005). As applied research, examining local perspectives of development interventions provides a key voice when considering sustainability in the development process.

'Livelihoods' as an object of research embraces the idea that members of a society are able to fulfill their aspirations and objectives through their local adaptive capacities and/or through extra-local development assistance. Livelihoods are diversified in a way that combine strategies to achieve a meaningful life (Nussbaum and Sen, 1993; Bagchi et al., 1998; Chambers, 1997; Ellis, 2000; King, 2011). Livelihoods can be measured by an individual's capability to sustain a quality life, considerate of the different combinations of strategies made available to achieve this life (Nussbaum and Sen, 1993; Robeyns, 2006). Extra-local development may influence opportunities for sustainable livelihoods. With regard to extra-local development assistance, questions arise as to how benefits at the local scale are actually perceived and acted upon (Chambers, 1997; Ferguson, 1994; Mabogunje, 1981). Development can promote positive change, have no effect, or have negative effects on communities at the local scale. Historically, development projects were implemented to achieve economic modernity and material wealth status. Poverty was measured by material assets, however, contemporary characteristics of poverty include key concepts such as empowerment, participation, inclusion, and accountability 
(Misturelli and Heffernan, 2010). Carr (2005) constructs the concept of "the household", and argues that it is critical for development studies to understand the complex structure of the household in order to acknowledge the variation of perceptions within. Development effect and how it is perceived and acted upon by local communities and individual residents provides the foundation of this study, where the overall problem is whether there is a 'connect or disconnect' between extra-local development initiatives and the adaptive capacities of local populations to achieve sustainable livelihoods. This research considers the effect of extra-local development on sustainable livelihoods, which is determined by whether or not an individual's livelihood is diversified, and whether or not their capability set is positively influenced.

Energy is crucial to sustainable livelihoods (Modi et al., 2005; Nussbaumer et al., 2012; Winkler et al., 2011) but its availability is impacted by global inequality issues, including access to income, food security, health and education (Nussbaumer et al., 2012). As global investments in local energy projects grow (sensu Sustainable Development Goals - United Nations), a larger number of people living in rural (local) communities are gaining access to electricity as a source of energy, but often at a great cost (Adkins et al., 2012; Davidson and Stanford, 2004; Parshall et al., 2009; Showers, 2011; Zvoleff, 2009). For example, rural electrification projects in East Africa is quickly emerging as a major influence on local livelihoods (see "Last Mile Connectivity Project"). In Kenya, the government has invested heavily in expanding the electric infrastructure to rural areas, however Lee et al., 2016 note that even though rural household electrification rate remain low (at roughly 5 percent), the majority of households are now "under grid," or within connecting distance of a low-voltage line. To address this, I focused on local perceptions of change in one rural region of Kenya and I examined how electricity is being introduced as a development initiative to the region and to what extent local people's energy use are being positively affected by the development initiative.

\subsection{Statement of the Research Purpose and Questions}

The purpose of this research is to employ a political ecological critique of electrification as a development initiative affecting the communities and livelihoods of the Kasigau Taita (Figure 1). Electrification, as any extra-local influence, is perceived globally as a potential major influence on rural livelihoods. For example, according to the International Atomic Energy Agency's (IAEA, 2005, 1) report Energy Indicators for Sustainable Development: “[a]dequate 
and affordable energy supplies have been key to economic development and the transition from subsistence agriculture economics to modern industrial and service-oriented societies." This research produces an alternative perspective - that of the local-by asking two research questions (Figure 1):

\section{How do the Kasigau Taita spatially and temporally map electrification efforts?}

Participatory geographic information system (PGIS) methods were utilized to produce data that are chronologically and spatially mapped with the assistance of local informants, focusing on their mapped chronology and descriptive narratives of the process.

\section{How has electrification influenced how residents are meeting their 'electrical'} energy needs? By talking with local people, narratives concerning how they meet their 'electrical' energy needs and how electrification is influencing those needs were recorded as locally validated accounts of an extra-local influence on local livelihoods. Their narratives provide a unique critique of the development initiative - local people are empowered when they are able to express the realities of their livelihoods. 


\section{Extra-Local Influence on Local Livelihoods}

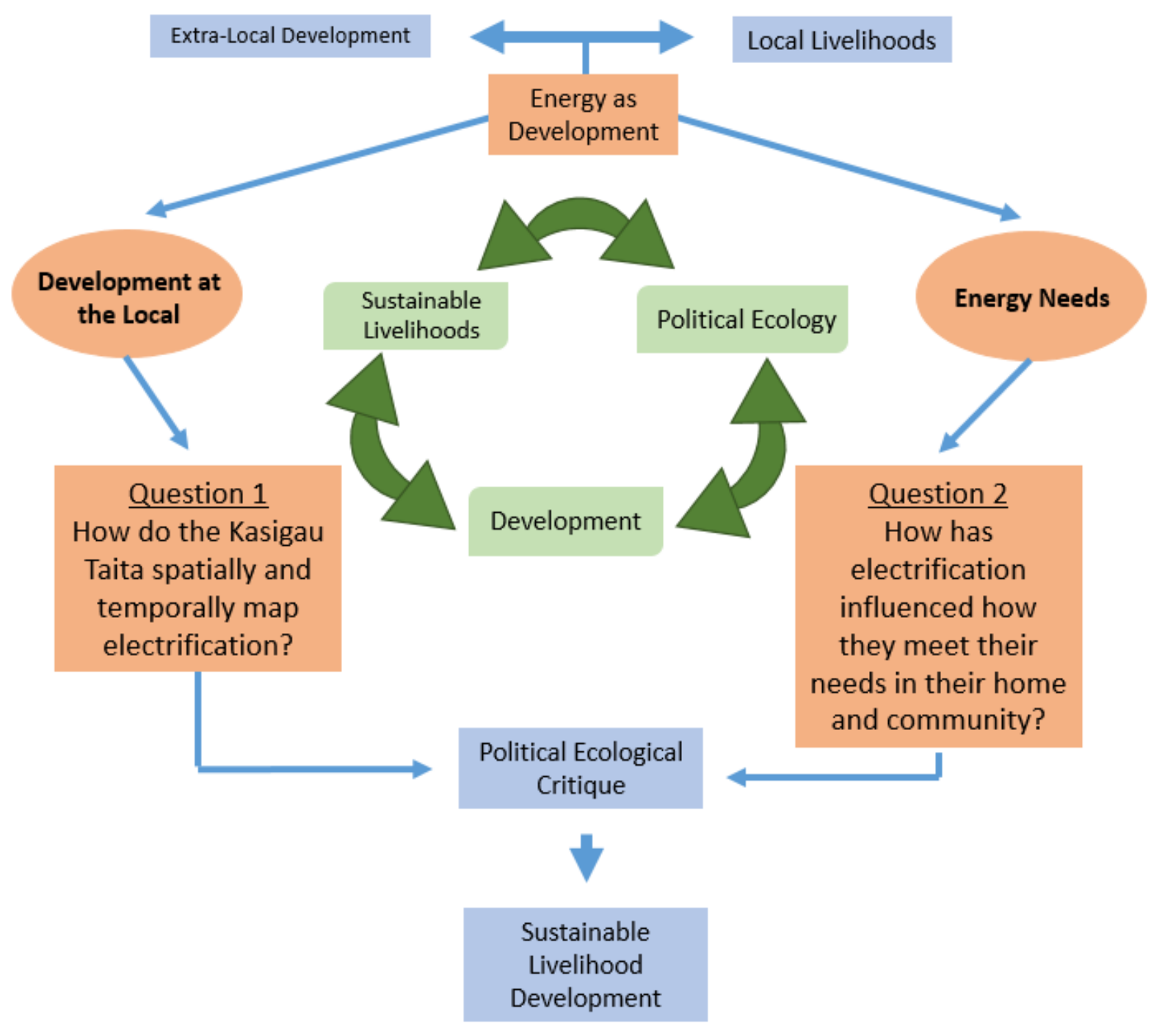

Figure 1: Conceptual model of the research framework.

\subsection{Contribution to Research}

The goal of this research is to represent spatially-explicit local narratives of the effects of a global influence on local livelihoods. The body of literature that currently considers different perspectives suggest that marginalized and underprivileged individuals often are capable of providing the most intimate, applicable knowledge (Chambers, 1994; 1997; Slocum, 1995). By process and outcome, this study explores, identifies and values local perspectives. 
This research focuses on electrification as a nationally important development initiative in Kenya that potentially changes energy use in rural settings. The study collaboratively compiles a map that can be used to explore physical-landscape and socioeconomic factors that might influence local connections, and then considers how its introduction influences electricity use as an energy source. How are people using electricity as a home or community resource, and how doe electricity play a role in their local livelihood strategies? Kenya is promoting an electricity development plan that is based on renewable energy sources but it's not clear if electricity only diversifies and increases overall energy consumption or if it can be used to offset more exploitative energy sources. At a very local scale, this study contributes views on how access to electricity influences energy use and its sustainability for households and rural communities. The research emphasizes by design that if a development program intends to improve the lives of people, those people's views and opinions should form an important basis for critique.

\section{CHAPTER TWO}

\section{Literature Review}

\subsection{A Theoretical/Conceptual Context in Political Ecology}

The theoretical context for this research lies within political ecology as a 'paradigm shift' in the study of human-resource relations (Neumann, 2005). Traditional cultural ecology studies explain human-environment relations at localities but fail to represent dynamic relationships between extra-local (outside) influences and local livelihoods. Political ecology introduces a new interactive model that focuses on how extra-local forces, such as ownership, labor, power and wealth in societies influence adaptive strategies for sustainable livelihoods. Development initiatives, as an extra-local intervention, can have positive effects, no effect, or negative effects on local livelihoods. Political ecology provides a conceptual framework that can be used to critically examine the intersection between development, as process and outcome, and local strategies for sustainable livelihoods.

Different conceptual frameworks can be employed in geographic research to hypothesize and accordingly examine the nature of human-environment relationships at different scales (Knight, 1992; "Roots and Branches" in Neumann, 2005). Defined in classic works by Friedrich Raztel (1896) and Ellen Semple (1901), deterministic perspectives hypothesize a linear effect 
where the physical environment determines local cultural development (environmental determinism) or provide possible options for societies (possibilism). In contrast, cultural determinism focuses on how the physical environment is being determined by human activity (Robbins, 2012, 26-48; Spiro, 2001). The flaws in these arguments, first defined in classic works by Carl Sauer (1965, see Robbins, 2012), challenged geographic research to consider a local interactive relationship, termed cultural ecology, between humans and the environment. "Sauerian human-environment research would concern itself with detailed study of the how of local cultures, less than the why" (Robbins, 2012, 36).

Cultural ecology matured over time into a complex field of study to examine human behaviors and practices in the context of their positioning in larger systems (e.g., Carney's examination of "Black Rice" or Steward's focus on subsistence versus work in Robbins, 2012). However, cultural ecology fails to recognize how local behaviors are influenced in significant ways from extra-local effects. A disinterest in the political economy limits cultural ecological studies (Robbins, 2012).

Political ecology, in contrast, identifies inherent power relations between extra-local and the local and introduces an alternative interactive model that accounts for more complex humanenvironment-power relations (Knight, 1992; Robbins, 2008; Robbins, 2012). Although political ecology discourse and epistemology continue to be debated, its focus on ecological relationships as influenced by a hierarchy of power remain strong (Blaikie, 2008; Robbins and Bishop, 2008; Rocheleau 2007). For example, political ecology challenged traditional development and environmental discourse in the 1980s by identifying how extra-local influences were affecting stresses on human livelihoods (Blaikie, 1985; Blaikie and Brookfield, 1987). Watts (2015, 33), through years of examining human adaptation and state policy in West Africa, strengthens political ecology as a critique of liberal economic policies:

[p] olitical ecology turned the flashlight inward toward commercialization of agrarian societies, to how communities were being torn asunder and radically reshaped by the twin processes of globalization and to how the exercise of power was indispensable to the understanding of the institutions of property, resource control, and market dynamics. 
Works in early political ecology highlight the complex relations between state governments and local livelihoods. Watts (1983) describes the political economy of agrarian society in Nigeria and the effect that famine, caused by a capitalistic approach to farming, had on peasant livelihoods over time. Pred and Watts (1992) evaluate the relations of power and culture and the effect of modernity and capitalism on the struggles of peasant society and developing national economies. These examples represent instances where the global political hierarchy forces agrarian societies to adapt to modernization influences. Electrification as a 'top-down' development initiative, makes it an important topic for critical inquiry in political ecology.

\subsubsection{Sustainable Livelihoods Approach}

The concept of 'sustainable livelihoods' is crucial to the theoretical context of this research because electrification is being introduced as an extra-local resource that influences the adaptive strategies of local energy consumption in relation to people's livelihoods. A 'livelihood' consists of a lifestyle that includes the capabilities, assets (both material and social) and activities required to live a meaningful life (Chambers, 1997; Ellis, 2000; King, 2011; Moriarty, 2002). Carr (2013) and others offer five types of "capital' in which livelihoods are generally framed; natural, physical, human, financial or social (79). These capitals are analyzed by following a series of "steps" which identify trends and stresses on livelihood assets, and examine the processes through which members of the community interact with each other and the larger society (i.e. policies, institutions) (80). Carr (2013) notes that there is a tendency within development literature to treat (local) social relations as a directly related to governmentality, and therefore only intelligible through the scope of the overall (extra-local) project. Livelihoods are positioned as a form of "intimate government", which renders a range of otherwise unrecognizable influences on decisions and outcomes that allow for a better understanding of the viability of a livelihood, and likely future livelihood pathways (Carr, 2013, 78). A livelihood is considered sustainable only when the availability of and access to assets can be maintained over time (e.g. securing reliable energy sources, access to water, etc.). Carr (2013) notes that if a household livelihood strategy functions only through the constant draw on one or more capitals, it is not a sustainable livelihood (80).

Sustainable livelihood studies especially consider how human capabilities are the means to livelihood fulfilment (Chambers, 1997). Measuring sustainable livelihoods can be addressed 
by assessing if an individual is able to achieve a valuable quality of life through diviserfied opportunities. The 'capability approach', pioneered by Amartya Sen, defines "functionings" as various activities a person can do when leading a life, and the "capability" of a person reflects the many possible combinations of various functionings that they chose to pursue (Nussbaum and Sen, 1993). Ellis (2000) defines “diversification” as ongoing social and economic processes that cause people to adopt intricate and diverse livelihood strategies (14). Therefore, as livelihoods are diversified through extra-local development initiatives, new functionings are introduced that influence an individual's capability to live a meaningful life. Energy security (or insecurity) at different scales (i.e. community vs. household) can be influenced by extra-local development, which possibly provides opportunities for new strategies to meet energy needs.

Livelihood studies, by definition, explore linkages between assets and the opportunities people possess that allow them to apply diverse assets toward their livelihood (Ellis, 2000). Chambers $(1988,9)$ coined the term "sustainable livelihood security" (SLT), focusing on the realities, opportunities, and constraints of poor and marginalized people. This framework challenges traditional "first-mode" thinking, by offering an alternative form of thought where marginalized people's realities are considered as the starting point for long-term sustainable livelihood security planning. This approach defines sustainable livelihood analysis as being considerate of not only the goal of positive livelihood effect, but also of the process that must be taken to achieve and sustain the goal over time (Chambers, 1988, 25):

"the conclusion is a paradox: population control, sustainable resource exploitation, environmental conservation, and rural development are all best served not by starting with them in a normal professional and departmental way, but by starting with people - the very poor and the poor - and what they want and need."

Sustainable livelihoods ensure that resource productivity is maintained or enhanced over the long term (Chambers, 1997). This concept may also be thought of in terms of a community's resiliency, or their capacity to 'bounce back' from stress or disturbance by natural events or human agency (Ellis, 2000). 
Sustainable livelihood research considers the goal of a development project as it supports processes that are required to promote positive change (Adams, 2002; Chambers 1988; 1997; Ellis, 2000; Scoones, 2009). 'Change' is an important concept in livelihood analysis. Often stresses on livelihoods begin with a change in socioeconomics or other stresses at the global or national scale, for example, reforms on farming practices in the developing world, a changing climate leading to droughts and flood, or changes in the struggle for land and power in the postcolonial world (Ellis, 2000; Watts, 1983;). These changes promote influences over the material well-being of communities, and also affect social and cultural aspects of livelihoods. This phenomenon is sometimes described as an alternative framing of livelihood research (Carr, 2013). As de Haan and Zoomers (2005, 32 - in Carr, 2013) note, "livelihoods is not a matter of material well-being, but rather that is also includes non-material aspects of well-being." By example, electrification represents a dynamic change being presented to a rural community as prescribed by global-to-national authorities. Sustainable livelihood studies especially consider how human capabilities may be influenced extra-locally but are always manifested locally (Chambers, 1997). Carr (2013) identifies the complexity of locally-specific social constructs, and argues that this complexity can be organized by focusing on why specific adaptations are implemented and how they affect livelihoods. King (2011) notes that livelihood research is particularly effective in evaluating production systems within larger structural constraints while also addressing the role of institutions in shaping access to opportunities. The introduction of electricity adds a new factor to the complex allocation of resources for human livelihoods. White et al. (2008) argue that electrification can positively affect development, but also impact social relations in complex ways. Policy makers can become empowered by not applying an overly simplified explanation of energy use (White et al., 2008).

\subsubsection{Development as an Extra-Local Effect}

Development, according to Sachs (1999) is an oxymoron - a term that was meant to mean one thing and ended up meaning the opposite. As an applied process, 'development' was supposed to end poverty, inequality and struggle. However, processes throughout the mid- $20^{\text {th }}$ century that were thought to be developmental at the time ended up widening the economic gap between the North and the South rather than closing it (Sachs, 1999). Some argue that the North's capitalistic interests in resources are what prompted intervention in the South. 
Development initiatives, from design to effect, continue to be under ongoing debate (Escobar, 1998; Ferguson, 1994). Despite this turbulent history, recent progress in development heavily influence this research. The history of popular themes in discourse and epistemology in development offer important context to the theory of this project.

Development in the 1970s was heavily influenced by material and individual factors of wellbeing, and focused on economic growth and modernization (Rist, 1997). Poverty was commonly thought of as individuals not having access to material benefits, such as food, water and money (Misturelli and Heffernan, 2010). Dominant epistemologies of the 1970s included Keynesian Economic, neoliberalism and the concept of "World Systems Theory" by Immanuel Wallerstein, which identified the 'semi-periphery' state of development (Willis, 2011). These materialistic views of poverty led to materialistic forms of development. While discourse in development in the 1980s remained firmly rooted in enhancing the economic wellbeing of people living in poverty, definitions of poverty began to include concepts such as powerlessness, vulnerability and isolation (Misturelli and Heffernan, 2010). Despite this, some (Peet and Hartwick, 2009; Rist, 1997; Watts, 1995; Willis, 2011) refer to this decade as "the lost decade of development". Influenced heavily by neoliberal economics, the South struggled against debt, inflation and a lack of investible funds to stay relevant on the global economic scale (Watts, 1995; Rist, 1997). By the 1980s, “dependency theories” accounted for much of the South's economic dependence on western societies. Critics of dependency theories argue that the goal (unintended or not) of Western the development of the South was based on the exploitation of natural resources rather than internal innovation (Peet and Hartwick, 2009). The South then became dependent on loans and assistance, making them more vulnerable to global influences. Marxist and neo-marxist theories were very popular and influential concepts in the 1980s, which critique the role of capitalism in systematic global economics. According to Rist (1997), the 1990s began on a note of hope, in which it was possible to imagine the development of the South as a priority and possibility. Traditional ideas of development were challenged. The concept of 'poverty' began to be widely accepted as a multidimensional phenomenon rather than strictly a lack of material assets (Misturelli and Heffernan, 2010). Influential feminist perspectives on inequality, poverty and gendered relations produced critiques of development, and issues raised by feminist development geographers became important to international agencies that deal with problems of development (Peet and Hartwick, 2009). The concept of 'anti-development' was 
introduced by James Ferguson (1994), and offers a critique of traditional development strategies, and evaluates the relations of power and culture and the effects of modernity and capitalism on developing national economies. Escobar $(1992 ; 1995)$ critiqued that development should be presented as a collaborative effort, and that grassroots approaches powerfully critique traditional values in the discipline. Postmodernists such as Corebridge (1993) argued that the capacity to act locally depends upon the ability to think globally. Participation and empowerment emerged as major themes within grassroots approaches in development (Chambers 1994; Willis 2011). Rist (1997) notes that development strategies for the South were not inclusive of the South. For example, up until the 1990s, the dominant theories that had been produced came from either the North, or from within international organizations (Rist, 1997, 198). This 'refocusing' of development strategies influenced epistemologies moving forward. By the 2000s, the new millennium brought momentum from previous decades and pushed for a vision of a newly constructed institutional framework (Peet and Harkwick, 2009). The 2000s and beyond have focused collective efforts to eradicate poverty in all forms. The 'rights based approach' (Cornwall and Nyamu-Musembi, 2004) and the 'capability approach' (Nussbaum and Sen, 1993) emerged as a theoretical framework in development and livelihood research.

More recent thinking in development represents a paradigm shift fueled by local knowledge and participation methods that target sustainable community development (Chambers, 1988; Chambers 1997; Ferguson 1994). This is, in a sense, a critique of traditional development strategies. More consideration has been given towards different scape of "local" development, such as the community scale versus the household scale. Carr (2005) explains that the 'household' has become, and will remain an important institution in development practice and theory. However, if development is to use the household as a means to understand and address complex social issues, it must cultivate a sensitivity to the local context: "New efforts must be aware of how the local definition and role of institutions like the household have seen changing constructions over time with reference to economic, environmental and other factors" (81). This paradigm shift represents the acknowledgement of unequal power and underrepresented local knowledge (Chambers, 1997). It challenges extra-local entities to accept a degree of disempowerment and to confront the issue of power with "altruism and generous behavior" (Chambers, 1997 in Putting the First Last, 134). My research utilizes this paradigm shift to offer critiques of electrification as development. 


\subsubsection{Energy as Development}

Worldwide, approximately 1.2 billion people do not have access to electricity (Nerini et al., 2014). Modern energy services are crucial to a country's economic development: “Access to modern energy is essential for the provision of clean water, sanitation and healthcare and for the provision of reliable and efficient lighting, heating, cooking, mechanical power, and transport and telecommunications services" (World Bank, 2017). Accordingly, electrification as a development initiative should have a direct effect on people's livelihoods and wellbeing. For example in 2003, Brazil proclaimed access to electricity to be a basic human right for all people, and since then the Brazilian government has invested in costly programs to provide electricity to the entire population (Nerini et al., 2014). It is generally agreed upon that energy is an important factor for sustainable development and livelihood wellbeing (Modi et al., 2005; Nussbaumer et al., 2012; Winkler et al., 2011) but development initiatives mostly focus on its extra-local introduction under national energy strategies, and there is much debate centered on the best strategies for achieving effectively electrifying rural areas. For example, Lee et al. (2016) demonstrated in Kenya that despite a high population density and extensive grid coverage seemingly ideal parameters for an electrification project - actual electrification rates for homes and businesses remained extremely low. My research questions whether making electricity available is indeed development by identifying how people afford and use electricity and/or if electricity positively affects livelihoods in response to its introduction. Winkler et al. (2011, 1038) states: "[o]verall, one can say that energy is a necessary condition for development, even though energy on its own is not sufficient."

Electrification effects on local livelihoods are accordingly related to accessibility, affordability, and control at different scales, i.e. community versus household (Winkler et al., 2011). A political ecological critique of electrification as a development initiative recognizes that the expansion of electrical grids (availability) in an area where the community would not be able to afford it (accessibility) may be a flawed approach to development. Winkler et al. (2011) argues that access to a grid connection does not guarantee use of electricity for all members of the population, in particular by poor households. According to the National Energy Policy drafted by the Kenya Ministry of Energy and Petroleum (KMEP), there are numerous socioeconomic reasons that electricity is specifically costly to the poor, including scattered populations leading to longer distributions, harsh terrains, demanding maintenance requirements, 
vandalism and high cost of connections (KMEP 2014, see chapter 4). In many cases, even if energy connectivity is expanded, the rural poor are most affected by the high costs of connection. For example, Parshall et al. (2009) developed a spatial electricity planning model to guide electrical grid extension, and conclude that connection costs could be around $\$ 2,000$ at the lowest in rural Kenya. Other models (Davidson and Stanford, 2004; Modi et al., 2005; Sanoh et al., 2012Winkler et al., 2011) echo this pattern that models generally tend to show electricity is costly to the poor. Showers $(2011,215)$ acknowledges that "discussions of electricity generally cent[er] on cost, and how best to reduce them." From a cost-use dynamic, electricity as a form of energy introduces new decision factors to household structures. Robbins (2011) describes a relevant example by considering the dynamics that a refrigerator would add to a household. In this case, the availability and affordability of the refrigerator has a direct effect on the freshness of food that a community may have access to. Similarly, the availability and affordability of electricity in a local community may have a direct effect on how resources are valued and used in their households.

\subsection{Methodological Context - Participatory Methods to Validate Local Knowledge}

My research employed a mixed methods approach that include several collaborative geographic methodologies (Bernard, 2000). Mixed method approaches recognize the value of both qualitative and quantitative research, for example combining positivist empirical observations with participatory mapping and oral histories (Rocheleau, 1995; Visser and Jones, 2010). Rhoads and Wilson (2010) acknowledge, “[t]he influence of spatial analysis - which focuses on measurements of properties and relationships that incorporate or are expressed in space - and its vision of observation have persisted as popular, viable ways to practice human geography. Nowhere is this influence more evident than in the application of geographical information systems to research problems in human geography" (32). Moreover, ethical obligations of participatory research guided a research process that better supports collaborative relationships between all research participants (Longhurst, 2006; Secor, 2010; Smith, 2006).

\subsubsection{Participatory GIS}

PGIS is a powerful tool that offers the ability to validate local spatial knowledge (Cope and Elwood, 2009; King, 2002; Robbins, 2003). King (2002) discusses several case studies that 
use PGIS in order to show its wide range of applications. For example, Peluso (1995) utilizes PGIS in an analysis of a regional planning program, which formerly did not include local villages on their maps, by employing local people to identify their locations. King (2002) explains how PGIS can be used to aid in the development of long-term planning projects. For example, Ashby et al. (1999) integrates PGIS and local knowledge when making suggestion for policy revisions for living in a hillside environment in Central America. The goal of PGIS is to represent the potential multiple meanings of space in geographic research, and to "challenge the epistemologies and representational limits that have been assumed in much of the literature" (Cope and Elwood, 2009, 58). PGIS provides an important method of collecting spatial data in a way that better engages local participants and re-centers the positioning of the research toward a focus on the 'local.'

Participatory field mapping (PFM) integrates local volunteers into landscape mapping (Slocum et al., 1995), employing focus groups and transect walks. Rocheleau (1995) used PFM techniques while seeking to represent people and places in the Rural Federation of ZambranaChacuey by combining several qualitative approaches with mapping in order to spatially represent the results. The combination of participatory methods and mapping allows for collaborative discussions about knowledge and space (Knigee and Cope, 2009), offering conversation on the relationships between the 'real' and 'perceived' characteristics of the spatial environment (Breitbart, 2006, 171).

Field mapping exercises include 'local experts' such as a village elder or a member of the community who has lived there long enough to have been able to observe processes of change under study (Kearns, 2000; Rice, 2006). Focus groups formed from these 'local experts' are an important traditional method that seeks to promote open, conversational dialogue between groups about a specific topic or research interest (Longhurst, 2006; Slocum et al., 1995; Secor, 2010). Focus groups are useful because they can facilitate constructive community conversation where participants can learn about each other's views on particular topics (Cameron, 2000).

Once focus groups are formed, the selected participants can describe landscape patterns along walked transects across the landscape, integrating joint observations of the physical environment human activities (Slocum et al., 1995). Transect walks consist of systematically walking a set transect line with local experts in order to observe the landscape, but more importantly to observe and interact with the participants (Chambers, 1997; Corbett and 
Rambaldi, 2009). Because there is no set protocol for participant observations (Laurier 2006), it is an open method that allows the researcher to gain detailed knowledge of local human interactions with places and people (see Kearns, 2000 for research in human geography). By combining focus group discussions with PGIS, the GIS data collected (transects, lines, points) can be given contextual attribute data that will be represented in the GIS analysis.

GIS techniques then offer an ability to incorporate contextual metadata (names, descriptions, measurements, comments, etc.) directly with raw vector data collected in the field (Batty, 2006). Although PGIS focuses on the representation of local narratives rather than analytical GIS functions (King, 2002, 47), GIS data analysis is an important part of PGIS (Cope and Elwood, 2009). For example, proximity analysis functions, such as the 'NEAR' tool, can be used to identify patterns and relationships in the space that is created between objects on the landscape and people (Malczewski, 1999; Mitchell, 2012). Monteiro et al. (2005) recognized that obstacles and terrain often determined where power lines were being constructed, and employed proximity analyses in order to show where the most cost-effective and economically accessible power lines could be built. The concept of 'cost vs. accessibility' is very important in literature concerning electrification (Modi et al., 2005; Nussbaumer et al., 2012; Parshall et al., 2009).

\subsubsection{Livelihood Analysis of Energy Use}

This research relies on a local assessment of livelihood diversification (sensu Ellis, 2000), as a measure of how rural populations adapt strategies in response to environmental or localextra local influences. Ellis (2000) offers methods for investigating livelihood diversification strategies that jointly employ fieldwork and participatory methods and are mainly focused on obtaining detailed information from households and individuals.

Local inquiry is, by definition, limited to the sampling approach (Rice, 2006). Sampling determines who will be asked to participate in interviewing and observation (Longhurst, 2006; Rice, 2006). Stratified sampling is an a priori approach which identifies people/homes from characterized subgroups, who are differentiated by some relevant characteristic (e.g., wealth, occupations or location, Rice, 2006). The goal of good sampling is not necessarily to generalize a population, but rather to include a representation and characterization of a population's diversity that guides the evaluation of their narratives (Rice, 2006). 
Semi-structured interviews are regarded as a core to good participatory research (Chambers, 1994, 1997). Interviews allow for flexible, open-ended, conversational dialogue between a researcher and participants (Dunn, 2000; Longhurst, 2006; Slocum et al., 1995). More specifically, household interviews allow the researcher an opportunity to gain a detailed understanding of the functions of a household (Kearns, 2000). For example, Ferguson (1994) used household interviews to structure economic lifestyles of mountain households in Lesotho. Interviews can be considered structured, semi-structured, or unstructured (Dunn, 2000). The semi-structured format allows for content-based dialogue, but requires that the interviewer act as an informal moderator who keeps the conversation topical (Dunn, 2000; Longhurst, 2006; Secor, 2010).

\subsubsection{Ethical Considerations for Participatory Research}

There are many ethical considerations that need to be made when conducting participatory research (Hay, 2006; Smith, 2010). First, one of the most basic considerations that a researcher is required to make is based on their positionality. Positionality refers to how the identity of the researcher influences the interactions taking place during the research (Kearns, 2000; Smith, 2006). Second, each participant must be completely informed and consent to the research process; their involvement in the project must always be voluntary (Smith, 2010). Third, the physical presence of a researcher can affect the dynamics of a community, especially if there is scientific research being conducted (Kearns, 2000). Fourth, keeping ties refers to staying in touch with the community that was researched after the fact (Smith, 2010). There should be a strong urge to savior the relationships created during field research by providing something as simple as a letter or picture, or an update of how the project is progressing (Slocum et al., 1995). Fifth, compensation is an often debated ethical consideration (Flicker et al., 2007). Although the poor are not often in control of where and when scientific research is conducted, they are usually the driving force behind participatory research (Chambers, 1997). They are employing their time in order to supply a product, so their time should be valued highly enough to be considered a research expense. Often, without their participation, the research could not be conducted. Therefore, compensation is an important part of participatory research. 


\section{CHAPTER THREE}

\section{Study Area}

\subsection{Kenya's Electric Infrastructure}

In 2014 , electricity provided $\sim 9 \%$ of the overall energy requirements in Kenya, while fossil fuels and renewable energy provided 22\% and 69\% respectively (Kenya National Energy Policy [KMEP], 2015). The total effective capacity for electricity contracted marginally from 2,263 mega-watts (MW) in 2015 to 2,253 in 2016 MW (KNBS, 2017). 'Effective capacity' is the capacity a power station, or system of power stations, is expected to achieve considering current operations (KNBS, 2017 - See Chapter 10). Additionally, total electricity generation increased from 9,514 gigawatt hours (GWh) in 2015 to 10,055 GWh in 2016 (Table 1; KNBS, 2017). Kenya's energy is produced from a variety of sources. In 2016, of the total electricity generation $(10,055 \mathrm{GWh})$, hydro power accounted for 3,959 GWh (39\%), geothermal accounted for 4,484 GWh (45\%), thermal oil accounted for 1,471 GWh (15\%), wind accounted for $56 \mathrm{GWh}(0.6 \%)$ and 86 GWh (.85\%) were imported (Table 1; KNBS, 2017). Some specific energy projects that are having an influence are the Lake Turkana wind project, the Menengai Crater geothermal exploration, and multiple hydroelectric dams along the Tana River. Specifically, Kenya's supply of geothermal energy is diversifying national electrical energy generation.

Table 1: Electrical energy supply by source in Kenya, and demand breakdown in 2016 (Kenya National Bureau of Statistics [KNBS], Economic Survey 2017)

\begin{tabular}{|c|r|r|r|r|r|r|}
\hline \multicolumn{2}{|c|}{ Supply (GWh) } & & & & \\
\hline Year & Hydro & Thermal Oil & Geothermal & Wind & Imports & Total \\
\hline $\mathbf{2 0 1 4}$ & 3,410 & 2,585 & 2,917 & 17 & 158 & 9,137 \\
\hline $\mathbf{2 0 1 5}$ & 3,463 & 1,412 & 4,521 & 60 & 59 & 9,515 \\
\hline $\mathbf{2 0 1 6}$ & 3,959 & 1,470 & 4,484 & 56 & 86 & 10,055 \\
\hline
\end{tabular}

\begin{tabular}{|r|r|r|r|r|r|r|r|r|}
\hline \multicolumn{2}{|c|}{ Demand (GWh) } & & & & & & & \\
\hline Year & $\begin{array}{l}\text { Small } \\
\text { Commercial }\end{array}$ & $\begin{array}{l}\text { Medium and Large } \\
\text { Commercial }\end{array}$ & $\begin{array}{l}\text { Off- } \\
\text { peak }\end{array}$ & $\begin{array}{l}\text { Street } \\
\text { Lighting }\end{array}$ & Rural & Exports & Losses & Total \\
\hline $\mathbf{2 0 1 4}$ & 2,963 & 3,891 & 34 & 22 & 504 & 31 & 1,692 & 9,137 \\
\hline $\mathbf{2 0 1 5}$ & 3,254 & 4,017 & 26 & 31 & 497 & 47 & 1,641 & 9,513 \\
\hline $\mathbf{2 0 1 6}$ & 3,315 & 4,146 & 32 & 46 & 513 & 39 & 1,965 & 10,056 \\
\hline
\end{tabular}


Before geothermal energy was utilized, much of Kenya's electric supply relied on hydroelectric power, which was largely determined by the amount of rainfall the country received. As geothermal potential continues to grow, Kenya has a new, more reliable source of electric energy that makes for a more reliable, diversified national electric grid supply. A greater reliance on geothermal is also decreasing its reliance on imported electric energy, which decreased from 2014-2016 (Table 1). Total domestic demand for electricity increased 2.9\%, from 7,826 GWh in 2015 to 8,053 GWh in 2016, while rural demand increased $3.3 \%$ to 513 GWh in 2016 (Table 1; KNBS, 2017).

As energy capacity and generation increase, so do access rates. In 2016, access rates in Kenya were reported to be 56\%, up from only 27\% in 2013 (ESI Africa, 2016). Increasing supply and demand of electricity in Kenya can be attributed to the lowering of connection costs, as well as a large increase in geothermal capacity and investments in rural electrification $\left(\mathrm{KNBS}_{\text {, }}\right.$ 2017; KMEP, 2014). To meet demands, Kenya imports electrical energy from surrounding countries. In 2016, it was reported that $96 \%$ of the electrical energy Kenya imported came from Uganda (Otuki, 2016; World Bank, 2017). With rising geothermal and wind generation, Kenya is able to lower its dependence on other countries by importing less electrical energy (Table 1).

Electric power transmission can be considered as high-voltage (HV) when it exceeds 33 $\mathrm{kV}$, medium-voltage (MV) when between $33 \mathrm{kV}$ and $1 \mathrm{kV}$, or low-voltage (LV) when it does not exceed $1 \mathrm{kV}$, according to the Kenya Energy Act 2006, Part 1, Section 2 (Parliament of Kenya, 2006, 19). Kenya's current high-voltage network connects the major urban centers of Nairobi, Mombasa, Nakuru, Eldoret and Kisumu, making electricity the major source of lighting, but rural infrastructure rates fall below 10\% in many places where other sources are used (Parshall et al., 2009). Kenya's transmission network is comprised of $1,434 \mathrm{~km}$ of $220 \mathrm{kV}$, and 2,513 km of $132 \mathrm{kV}$ line (KMEP, 2014). Electric energy is distributed nationally at $132 \mathrm{kV}$ via large transmission pylons. High voltage electricity is transformed to a medium voltage at regional substations, and is distributed regionally at either $33 \mathrm{kV}$ or $11 \mathrm{kV}$. Once a regional distributions reaches a rural location, electricity must first pass through a local transformer to be transformed into $220 \mathrm{~V}$, the common household distribution voltage. 


\subsubsection{National Strategies for Rural Electrification}

National policies and local geographies influence strategies for electrification at the rural scale, which rely on foundational geographic concepts. For example, expanding national grids is inherently spatial, being influenced by the physical location of powerlines, transformers, and people; and maximizing the efficiency of the existing electrical grid is done my lowering connection costs that affect local economics and household decision making. Rural electrification efforts present many challenges, which, according to the Kenyan Rural Electrification Authority (REA), include high connection costs, high operating costs, harsh terrains and vandalism. Electricity is not commonly available or used as a primary energy source in rural Kenya but that demand is increasing. As of June $30^{\text {th }}, 2013,28.9 \%$ of the Kenyan population was connected to electricity (KMEP, 2014). This figure is the result of the Kenyan Government establishing the REA under section 66 of the Energy Act No. 12 of 2006, developed in order to accelerate the pace of rural electrification and promote sustainable socio-economic development (KMEP, 2014). Additionally, projects like the Last Mile Connectivity Project, which aims to maximize the efficiency of rural electrical transformers and build new transformers to offer more connections to rural households, are being implemented in order to meet Kenya's national goal of 100\% electricity availability by 2020 (KPLC ,2016b). Under this program, the number of customers connected to electricity in Kenya expanded 38\% between 2015 and 2016 (KNBS, 2017). Rural communities are recognizing potential benefits of electrification. For example in 2013, the Taita Taveta County Primary School Task Force filed a detailed report concerning the declining standards of education (TTCG, 2013a). This report concluded that $52.17 \%$ of pupils currently in the county use lantern lamps to read and study, while only $20 \%$ have access to electricity (TTCG, 2013a). In addition: "poor lighting has affected completion of homework and encouraged poor reading culture leading to poor performance" (TTCG, 2013b, 57).

In 2004, new national electrical connection policies were implemented in Kenya influenced by a new political dispensation in 2002, which was intended to service "more enlightened customers" (KPLC, 2016a). This policy stated that potential customers within a 600 meter radius of a distribution transformer would pay a standardized fee for a single-phase or three-phase connections equal to 32,480 Ksh and 44,080 Ksh respectively (KPLC, 2016a). 
Generally, single-phase connections are designated for residential use while three-phase connections are designated for industrial connections.

In 2016, Kenya Power reported managing a system with approximately 40,000 active electrical transformers nationwide (KPLC, 2016b). Electrical transformers are necessary because they convert the high-voltage energy $(132 \mathrm{kV})$ from national distribution into a suitable voltage for household use $(220 \mathrm{~V})$. Although the installation of new transformers increased access rates in Kenya, actual connection rates remain low, especially in rural areas (Lee et al., 2016). The Kenyan government and the African Development Agency (ADA) recognize the importance of rural electrification, and therefore implemented the ADA-funded 'Last Mile Connectivity Project' (LMCP) to address the struggles of rural electrification. The project aims to:

"facilitate the objective of affordability concerning Kenyan households to the national network grid. This is geared towards achieving a national connectivity rate of $70 \%$ by 2017 and part of the government's goal of a universal access to electricity by 2020 ....[Additionally] to benefit from this project, customers within range of selected transformers will be required to contribute a total of KShs. 15,000 for each single phase connection" (KPLC, 2016a).

The LMCP is split into four phases. Phase one (April 2016) focused on maximizing the potential of existing transformers in designated areas by connecting customers at a lower cost $(15,000$ Ksh). Phases two, three and four will focus on maximizing existing transformers and installing new transformers with funds allocated respectively by the World Bank (Phase 2), African Development Bank (AfDB - Phase 3), and a combination loan from the Agence Francaise de Developpement (AFD)/European Union (EU)/Eurpoean Investment Bank (EIB)(Phase 3) (KPLC, 2016b)

My research occurred within the first phase of the project, which focused on maximizing the use of existing transformers by connecting more people at a lower connection cost. However, due to the amount of active industrial and residential electrical transformers in Kenya $(>40,000)$, only a select few transformers were chosen to be included in the first phase of the LMCP, which ensures customers with a lowered connection fee of 15,000 Ksh. According to the "LMCP Project Phase" report, which identifies all transformers $(n=5,320)$ affected by this project by 
number, constituency and public utility description, the transformers placed at Mt. Kasigau, in the Voi constituency, are not included in the first phase of the project.

\subsection{Mt. Kasigau}

Mt. Kasigau ( $3^{\circ} 49^{`} \mathrm{~S}$ and $\left.38^{\circ} 39^{`} \mathrm{E}\right)$ is located in Taita-Taveta County, Coast District, in south-western Kenya, approximately $115 \mathrm{~km}$ west of Mombasa (Figure 2). The mountain is the most northeastern and isolated mountain in the ancient crystalline Eastern Arc that also include the Taita Hills and Mount Sagalla in Kenya. Kenya's Eastern Arc Mountains are located in a corridor between Tsavo East and Tsavo West national parks, the largest protected area complex in Kenya, which occupy $65 \%$ of the total land in Taita-Taveta County. Kasigau Location, an electoral ward of Voi, has an approximate area of 1,653 km² (TTCG, 2013a).

Mt. Kasigau rises steeply from 600 to $1641 \mathrm{~m}$ in less than $2 \mathrm{~km}$, which allows for the capture of enough moisture from the Indian Ocean to support an evergreen forest above $1000 \mathrm{~m}$ and provide a piped water supply to five villages at its base: Rukanga, Jora, Kiteghe, Bungule, and Makwasinyi. Mt. Kasigau's isolation has been a historically significant factor, as populations in the area are familiar to adapting to isolation and adverse conditions (i.e. drought, food shortages) and employing diverse strategies to sustain their livelihoods. Moreover, low and unpredictable rainfall patterns contribute to insecure food production systems and much variability in livelihood condition (Medley et al., in press). 


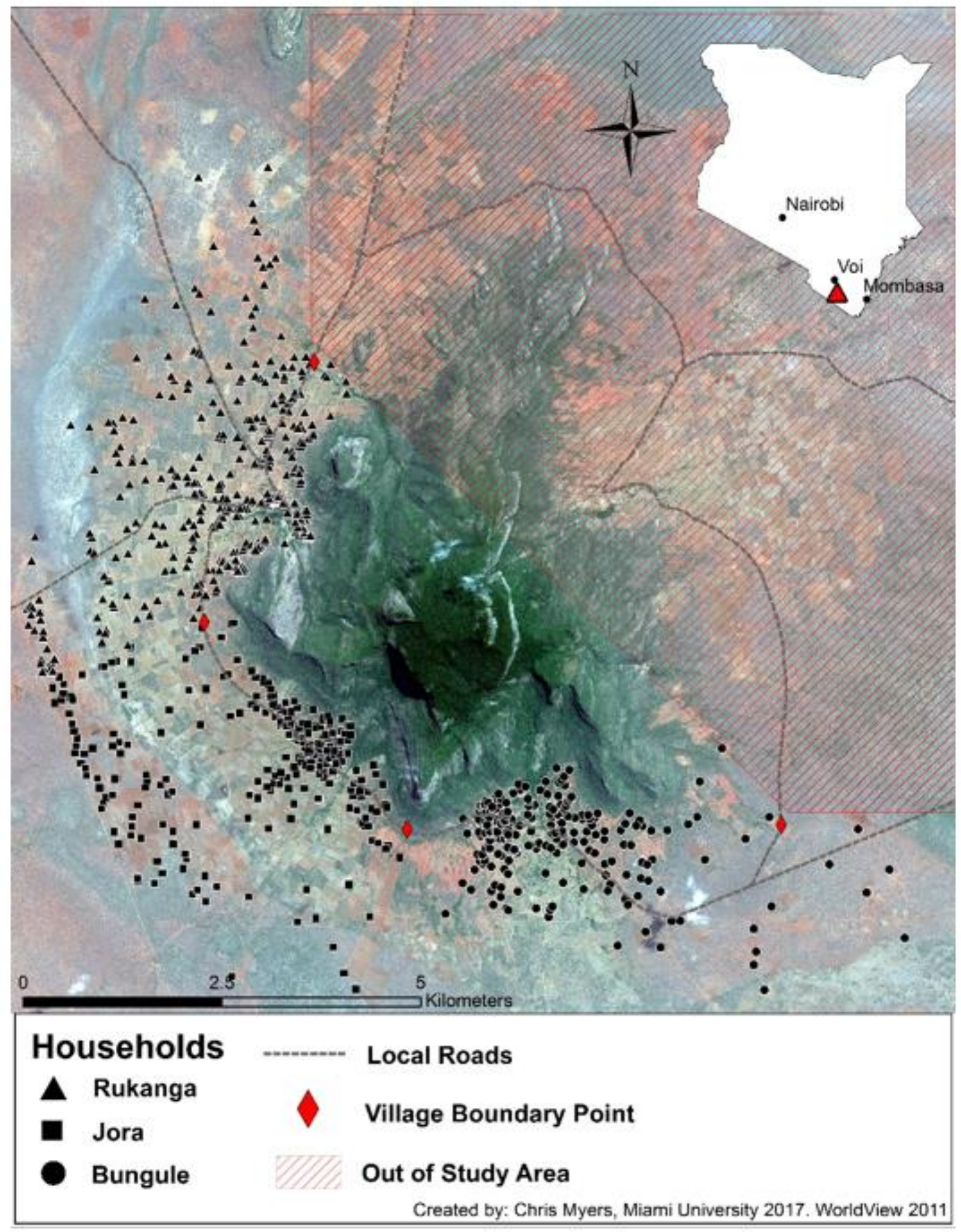

Figure 2: Mt. Kasigau, Kenya, showing identified homes on the 2011 Worldview image in the three study villages. 


\subsection{The Kasigau Taita}

My personal experiences in Kenya have lent detailed context to the beauty of the landscape and the uniqueness of the people, however, they have also taught me of the struggles that rural African communities constantly face. I feel that these communities have come to be misrepresented. Rich cultural traditions and complex local realities of marginalized communities are often shadowed by over-arching themes of poverty, seclusion, and simplicity. While it may be true that these types of communities are dealing with less material infrastructure, the fact is that their realities operate in complex webs of socioeconomic hierarchies and traditional lifestyles with deep roots in the landscape. As modernization influences nations all over the world, these types of communities are being put at an increasing risk of stressed livelihoods due to global influences. It is extremely important that considerations are made for these factors influencing rural communities.

My research focused on three villages - Rukanga the market center, Jora and Bungule at the base of the mountain (Figure 2). The 2009 Kenya population census reports 3,965 people in 942 households for the three study villages, or an average household size of 4.2. At Mt.

Kasigau, family farms are distributed across lateritic and black cotton soils in lowland bushland and/or near their homes at the base of the mountain, but residents showed former farm locations and described traditional rights to lands on the mountain (Kalibo and Medley, 2007). As mainly a subsistence farming community, the Kasigau Taita have had to adapt to drought and unpredictable rainfall in order to meet food needs, and their livelihoods are vulnerable, positively and negatively, by outside interventions that contribute to national-to-global economic development strategies. Validating local knowledge of the Kasigau Taita on the introduction of electricity to their communities provides an opportunity to explore how one major development initiative influences their livelihoods. 


\section{CHAPTER FOUR}

\section{Data and Methods}

This research was employed to narrate local spatial representations of the introduction and spread of electricity at Mt. Kasigau, and to compare local perceptions of electrification as a development initiative. As human subject research, the study design followed guidelines and gained approval from Miami University's Institutional Review Board for Human Subject Research (Appendix 1). Upon arrival, I identified a research assistant who acted as a guide, translator and interpreter (Kasigau Taita and Swahili to English) around the region. I employed Joseph Mwamodo as a research assistant, who has been involved with academic research conducted by Miami University at Mt. Kasigau under a three-year NSF project. He assembled field research groups for the participatory mapping exercises and helped set up interviews with households.

The PGIS field mapping exercise and home interviews were conducted in Jora, Rukanga and Bungule in respective order. Village boundaries were described by local participants, and mapped onto a 2011 Worldview-2 1.84 meter resolution satellite image. Using 2009 census data, the village boundary dataset, and identified homes on the Worldview 2 image, populations for each village study area were estimated. The average household size of 4.2 was multiplied by the number of identified homes in each village boundary to estimate village populations.

\subsection{Participatory GIS Mapping of Electrification at Mt. Kasigau}

To address my first research question, I employed participatory field mapping techniques and GIS analyses to map and spatially describe the electrification infrastructure at Mt. Kasigau. Mr. Mwamodo identified a village elder, and 2-3 village representatives to assist in the field surveys. These groups relied on recommendations from my research assistant and recommendations from village elders who formerly worked with MU research. We selected adult 

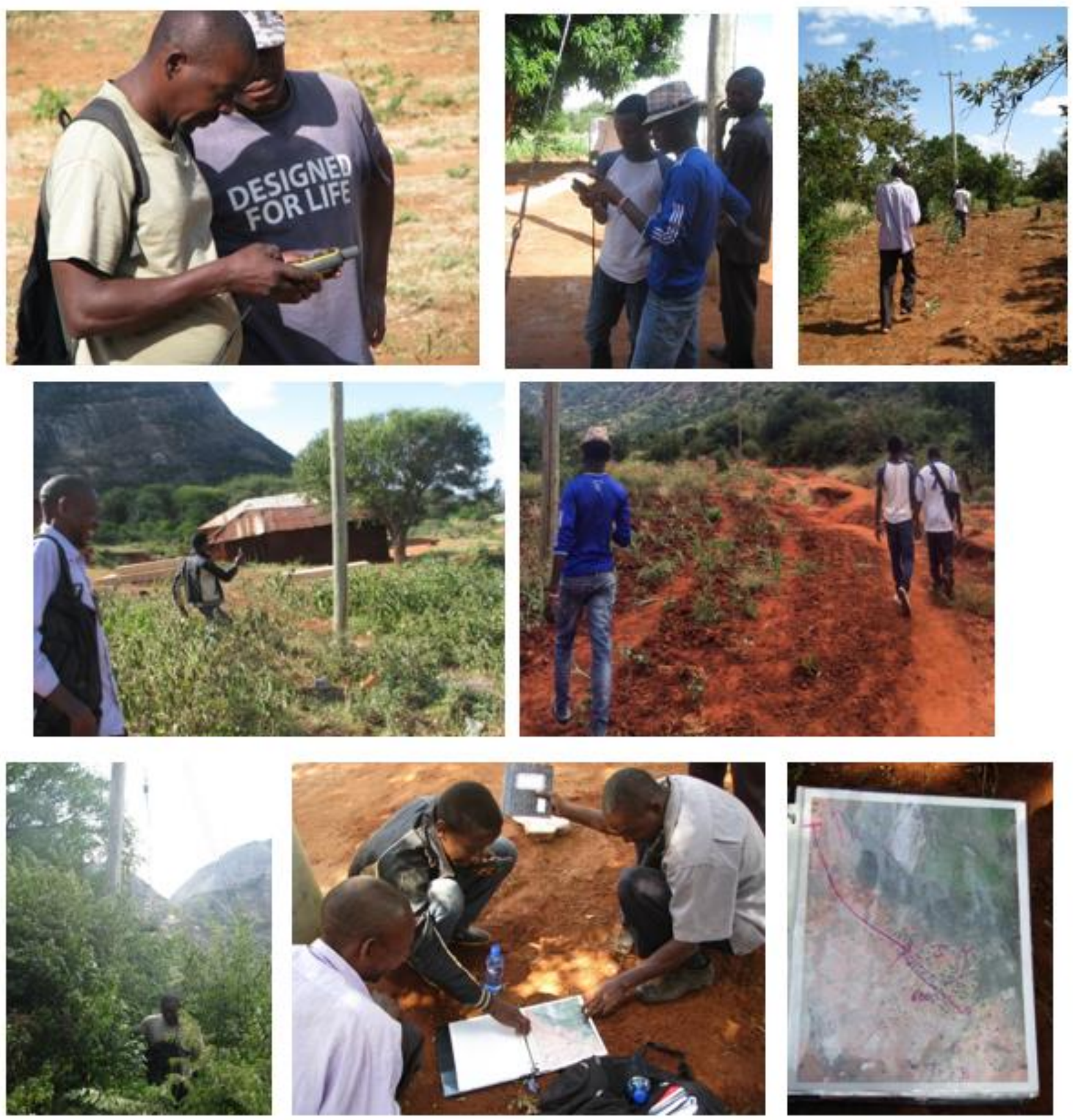

Figure 3. Participant mapping was conducted by members of the villages. Joseph Mwamodo assisted in instructing participants on how to use the GPS units. In the field, participants often took turns using the GPS units while we navigated the power lines, while the elder usually chose to walk in the front or back of the line. The 2011 WorldView image aided as a spatial reference to the groups while in the field. 
individuals who were familiar with the region and who were able to help identify processes of change and expansion in the electrical infrastructure (Figure 3).

The participatory mapping exercises began by familiarizing the group members with the Garmin GPSMAP 62 GPS units obtained from the Miami University Geography Department. These GPS units are a basic model with functions such as marking points, naming points, recording transects, and providing orientation. I first introduced my research assistant to the GPS unit, who then aided in familiarizing other group member with the procedure (Figure 3 ). The groups recorded and named tracks along electrical lines, and they marked and named points at connections. Group members often embraced different roles during the mapping exercises. For example, the village elder often chose to either be in the front or back of the group, and did not use the GPS unit. The other group members either led the group with a panga (machete) in order to clear paths for mapping power lines or managed the GPS units. Group members usually alternated tasks on different days.

The village groups identified a specific point to begin mapping, usually located in the center of the village being mapped. From this point, the field groups agreed upon which direction to proceed with the mapping, often related to the number of powerlines. Often, the group utilized the 2011 WorldView-2 image, which was sectioned, printed and laminated, for providing an aerial view of the study area. Dry erase markers were used to draw on the images while the groups were deciding how to proceed (Figure 3). When mapping started, points were taken at any structure that had an active electrical connection. Initially, a nomenclature system was being used to name points according to their type, however this technique was quickly abandoned because naming individual points on the GPS units proved to be time consuming and inaccurate if done incorrectly. Instead, points were given their default name that consisted of a three-digit number that was recorded in a notebook alongside a description of the point. Points were then uploaded into ArcMap GIS software at the end of a work day, and descriptive fields were added to the point data. Each connection was symbolized as a business, public service, or private home. Field data collection in each village lasted approximately one week.

The compiled GIS data included all connected homes, businesses and public services, all power lines, and a representation of the electrical transformer service areas. We also documented, to the extent possible, the chronology of power line installation. The participants did not know the exact dates for each connection, so we focused on a rank ordering of the lines 
in the three villages. This system assigned individual lengths of power line with a specific order that indicated its relative age. A line was considered a main line if it carried the distribution voltage of 11 $\mathrm{KV}$ to the local transformers which transform it to $220 \mathrm{~V}$, the common household distribution voltage. A line that diverged directly from a first-order line was ranked as second-order, and any line that diverged directly from a second-order line was ranked as third-order (Figure 4).

Methods in proximity analysis were applied to determine distances between connected households and the main power line. ESRI defines proximity analysis as "a type of analysis in which geographic

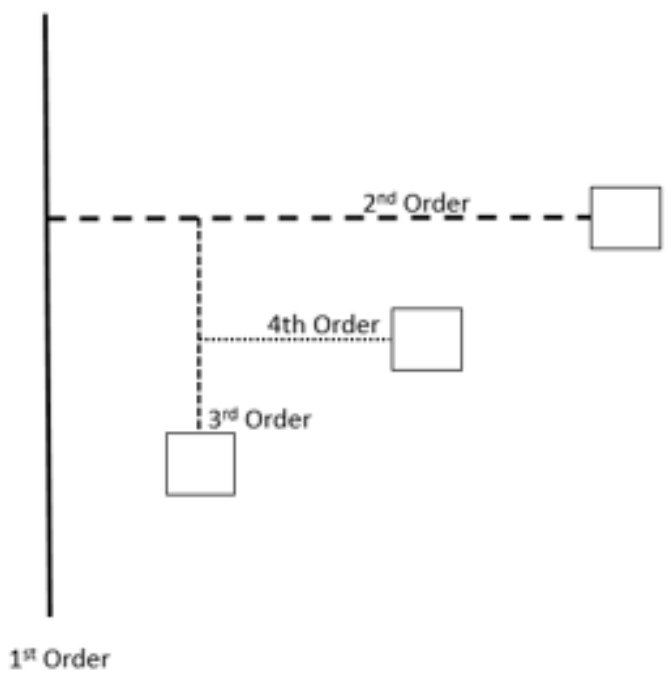

Figure 4: A line ordering system that assigns a value to a power line based on the order in which it was connected from the main distribution line features (points, lines, polygons, or raster cells) are selected based on their distance from other features or cells. Distances from connected households to the first order, or main line, were calculated using the 'NEAR' tool in ArcMap 10.3 proximity analysis toolset. These calculations were conducted in order to illustrate the spatial relationships between the first order, or main power line, and expansion in electrification at Mt. Kasigau.

\subsection{A Livelihood Analysis of Energy Use}

My second research question sought to understand how household's energy needs are being influenced by the introduction of electricity to Mt. Kasigau. Semi-structured interviews guided conversations with village residents at their home. My field assistant, Mr. Mwamodo, assisted in choosing households to interview, which were stratified among the three villages. Most of the interviews were conducted in Swahili and/or Taita and translated to and from English by Mr. Mwamodo. I recorded the conversations with pen and paper, and compared notes with Mr. Mwamodo at the end of the session.

Some introductory information was first collected, including who was being interviewed, how many people lived in the household, and whether the household was connected to the national electrical grid or not. Participants were then asked to identify how they are currently 
meeting energy needs, and to identify how electrification has influenced (if at all) how they meet their energy needs (Table 2). Their narratives identified the role of electrification on energy needs as well as alternative methods for meeting energy needs. Interview questions focused on asking how energy needs are met, how grid connection affects energy use, cost and reliability of electricity, and perspectives on Kenya's rural electrification plan (Table 2). Those interviewed were generally the woman and/or the man "of the house." Each household had a unique perspective to offer, so the open-ended conversations generally ranged among the interviews.

Table 2: A list of questions which guided the household interviews.

\section{Question}

How are electrical needs met in the home?

- How do you meet electrical energy needs in your home for lighting or phone charging?

- What are your electrical uses in your home?

Access to and use of on-grid electricity

- How does connection to the grid in the community and/or you home influence your life?

Cost and reliability of electrical energy and alternative sources

- How reliable is electricity at Mt. Kasigau?

- Are the electric grids in the community reliable, or do they go down often? Are the repaired quickly?

- Do you know the current fees for connecting to the electrical grid?

- Are these current fees affordable?

- How much did you pay, or would you be willing to pay, to connect to the electrical grid in your home?

- How does connecting to the grid compare with the affordability and/or reliability of other alternatives (solar)?

- How do the costs of kerosene, grid connection and/or solar panels influence how you decide to invest in energy?

Perspectives on Kenya's plan to expand on-grid electrical use

- Do you think the national plan to extend electricity to Mt. Kasigau was a good plan?

- What would be your recommendation for the project going further?

- Do you think that the government/energy providers understand the energy needs of rural people?

- Do you think that the introduction of electricity has helped the community grow? 


\section{CHAPTER FIVE}

\section{Results}

\subsection{Spatial and Temporal Mapping of Community Electrification}

\subsubsection{Electrical Infrastructure for the Mt. Kasigau Study Region}

Kenya's electrical power expanded to the study area via large transmission pylons maintained and operated by Kenya Electricity Transmission Company Limited (KETRACO). KETRACO is also responsible for the local transformation of power to a lower voltage that is more suitable for customer use at substations. The electrical substation for Mt. Kasigau is located in Voi ( $\sim 50 \mathrm{~km}$ distant), where energy is transferred about $26 \mathrm{~km}$ along the Nairobi-Mombasa Highway at $132 \mathrm{kV}$ to Maungu, where it is then transformed into $33 \mathrm{kV}$ and $11 \mathrm{kV}$. Energy is then distributed $\sim 32 \mathrm{~km}$ to Mt. Kasigau at $11 \mathrm{kV}$. The first transformer and power lines reached the mountain from the village of Maungu in 2009 and now extend around the mountain. The electric infrastructure consists of power poles, power lines and transformers. Power poles are either wooden or concrete, as Kenya Power (2012) designates that power poles must be suitable to withstand a single-transformer mount. Power lines consist of either full copper or aluminum wires, and transformer specifications vary based on requirements (Kenya Power 2012). While Kenya Power and Lighting Company officials and local observations provided an instrumental description of its introduction to the Kasigau location, local narratives collected in the field described problems that affect the quality of the rural electrification infrastructure at Mt. Kasigau (Figure 5).

Power is distributed to individual locations (homes, businesses, or public services) at $220 \mathrm{~V}$, passing first through a local transformer. Field observations, an informal interview with a local electrical installer, and an interview with Kenya Power and Lighting Company officials confirmed that each transformer services a 600 meter radius. The rural electrification network, therefore, depends on the quantity and placement of local transformers. At Mt. Kasigau, we mapped eight electrical transformers and an overall transformer service area equal to $8.3 \mathrm{~km}^{2}$ (Figure 6). Since all household-level power distribution occurs at 220V, a physically larger transformer is necessary in a location where more customers are being serviced or more energy is needed for the service within the area. For example, two much larger transformers are located next to Safaricom towers in Rukanga and Bungule, respectively (Figure 6). From the eight 
transformers, we mapped 164 connection points to businesses (55), homes (91) and housing complexes (3), and different public services (15), including a health clinic, three primary schools, a secondary school and a polytechnic school, five churches, three boreholes, and a library. The total length of power lines mapped in the study area is 23,215 meters.

"[Kenya] is producing a lot of power and using it to supply the infrastructure. Rural electrification - it's not always reliable. There are many problems with the procedures. Vandalism is the main problem. It is hard to maintain things when they are being vandalized. Technical problems occur; every mechanical infrastructure will have technical problems, which need to be maintained. This requires time, effort, and workers. At Kasigau, supply comes from the Kenya Pipeline at Maungu. The transformer at Maungu needs to be updated. Ants and

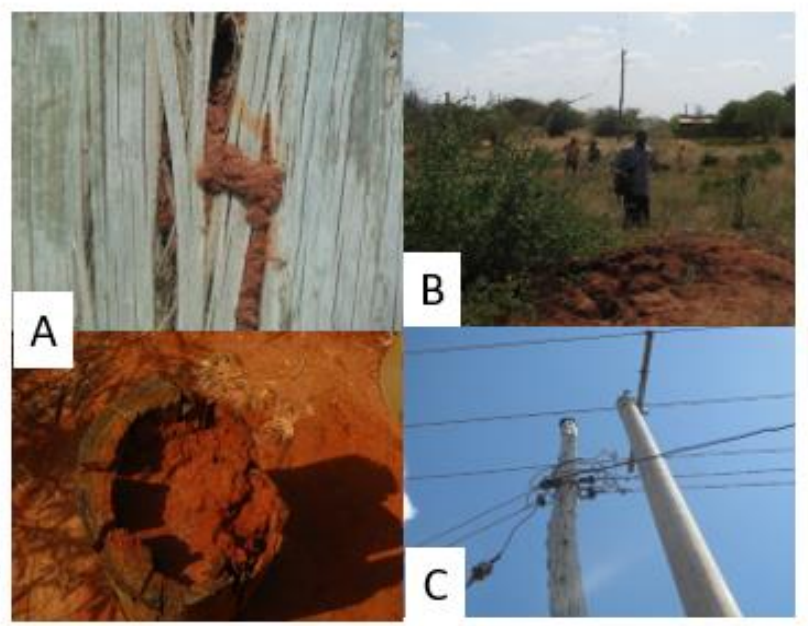
termites eat the inside of the wooden poles, which then have to be replaced.

Figure 5: A narrative and photos which highlight the local constraints on the quality of the local infrastructure, especially ants and termites damaging wooden poles (A), which was observed in the field (B - termite hill). Wooden poles must be replaced with concrete poles (C) 


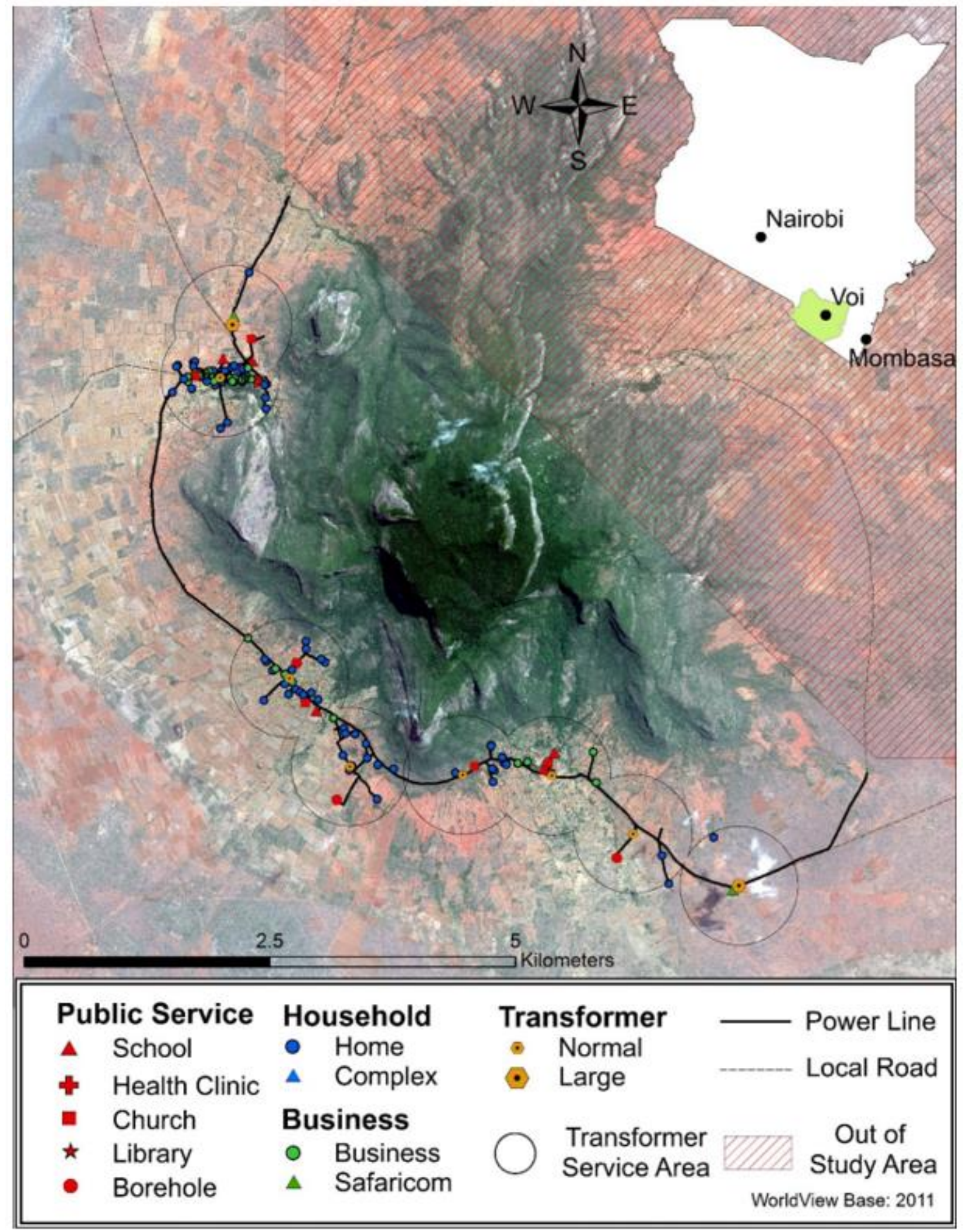

Figure 6: A map depicting the results of the participatory mapping exercises. 


\subsubsection{Comparison of Electrical Provisions among the Study Villages}

Based on the village boundaries agreed upon by the study participants, we mapped two transformers in Rukanga, two in Jora, and four in Bungule (Figure 6). Comparatively, the transformer service areas vary among the three locations, though the length of power lines were approximately equal (Table 3a). Variability in transformer service areas occur due to overlap in service boundaries influenced by the proximity of transformers to one another. For Rukanga, we mapped a settlement area at $15.8 \mathrm{~km}^{2}$, and the transformer service area totaled $1.8 \mathrm{~km}^{2}$ or $11.4 \%$ of this land area (Table 3a). The 2009 population in Rukanga was estimated at 1,869 with a potential serviced population of 714 (170 households multiplied by an average household size of 4.2), indicating $38 \%$ availability (Table $3 \mathrm{~b}$ ). The Jora boundary totaled $13.7 \mathrm{~km}^{2}$, and the transformer service area totaled $2.2 \mathrm{~km}^{2}(16.1 \%)$ (Table 3a). The population in Jora was estimated to be 1,184 with a potential service population of 596, indicating $50 \%$ availability (Table $3 \mathrm{~b}$ ). The Bungule boundary totaled $15.3 \mathrm{~km}^{2}$, and the transformer service area totaled 4.3 $\mathrm{km}^{2}(28.1 \%)$ (Table 3a). The population in Bungule was estimated to be 1,045 with a service population of 747 , indicating $71 \%$ availability (Table 3b). Therefore, Bungule had the greatest service availability even though it had the lowest population. There was one gap in service of about $2.4 \mathrm{~km}$ between Rukanga and Jora (Figure 6). Although the centers of Rukanga and Jora are both serviced, many homes are located outside of the village centers where electrical service is not available.

Table 3a: Comparison of total area to serviced area per village

\begin{tabular}{|l|c|c|c|}
\hline A. & Total Area $\left(\mathrm{km}^{2}\right)$ & $\begin{array}{c}\text { Transformer Service } \\
\text { Area }\left(\mathrm{km}^{2}\right)\end{array}$ & $\begin{array}{c}\text { Percent } \\
\text { Serviced } \\
\mathbf{( \% )}\end{array}$ \\
\hline Village & 15.8 & 1.8 & $\mathbf{1 1 . 4}$ \\
\hline Rukanga & 13.7 & 2.2 & $\mathbf{1 6 . 1}$ \\
\hline Jora & 15.3 & 4.3 & $\mathbf{2 8 . 1}$ \\
\hline Bungule & $\mathbf{4 4 . 8}$ & $\mathbf{8 . 3}$ & $\mathbf{1 8 . 5}$ \\
\hline Total & \multicolumn{3}{|}{} \\
\hline
\end{tabular}


Table 3b: Estimation of total serviced population based on an estimated average household size of 4.2 .

\begin{tabular}{|l|c|c|c|c|c|}
\hline B. & $\begin{array}{c}\text { Total } \\
\text { Number of } \\
\text { Households }\end{array}$ & $\begin{array}{c}\text { Total } \\
\text { Estimated } \\
\text { Population }\end{array}$ & $\begin{array}{c}\text { Estimated } \\
\text { Serviced } \\
\text { Households }\end{array}$ & $\begin{array}{c}\text { Estimated } \\
\text { Serviced Population }\end{array}$ & $\begin{array}{c}\text { Percent } \\
\text { Pop. } \\
\text { Serviced } \\
\text { (\%) }\end{array}$ \\
\hline Rukanga & 445 & 1,869 & 170 & 714 & $\mathbf{3 8}$ \\
\hline Jora & 282 & 1,184 & 142 & 596 & $\mathbf{5 0}$ \\
\hline Bungule & 249 & 1,045 & 178 & 747 & $\mathbf{7 1}$ \\
\hline Total & $\mathbf{9 7 6}$ & $\mathbf{4 , 0 9 8}$ & $\mathbf{4 9 0}$ & $\mathbf{2 , 0 5 7}$ & \\
\hline
\end{tabular}

The study mapped a total of 164 electrical connection points, which included 93 connection points in Rukanga, 41 in Jora, and 30 in Bungule (Table 4). Rukanga is recognized as the commercial center at Kasigau where we measured connections to 46 businesses, 39 homes, three housing complexes and five public services, including Moi Boys High School, Rukanga Primary School, two churches and a regional health clinic (Table 4). Internet services to the public were provided by one internet cafe. In Jora, connections were mapped to five businesses, 32 homes, and 4 public services, including the Jora Primary School, one church, and two public boreholes (Table 4). In Bungule we mapped connections to four businesses, 20 homes, and 6 public services, including Bungule Primary school, Bungule Youth Polytechnic School, the Amy Nicholls Memorial Center and Library, and two churches (Table 4). Bungule offers the most service area among the three villages, but has the least number of structures actually connected. Comparatively, Rukanga has the smallest serviced area due to overlap in transformer service area (Figure 6), but has the most structures connected, and particularly the most number of businesses and the regional health clinic in the area.

Table 4: Distribution of connected points at Mt. Kasigau, categorized by village and building type; Business (green); Living Place (blue) or Public Service (red).

\begin{tabular}{|c|c|c|c|c|c|c|c|c|c|}
\hline Village & Business & Household & Housing Complex & $\begin{array}{l}\text { Health } \\
\text { Clinic }\end{array}$ & School & Church & Library & Borehole & Total \\
\hline Rukanga & 46 & 39 & 3 & 1 & \begin{tabular}{|l|}
2 \\
\end{tabular} & \begin{tabular}{|l|}
2 \\
\end{tabular} & \begin{tabular}{|l|}
0 \\
\end{tabular} & 0 & 93 \\
\hline Jora & 5 & 32 & 0 & 0 & 1 & 1 & 0 & 2 & 41 \\
\hline Bungule & 4 & 20 & 0 & 0 & 2 & 2 & 1 & 1 & 30 \\
\hline Total & 55 & \multicolumn{2}{|r|}{94} & \multicolumn{5}{|c|}{15} & 164 \\
\hline \multicolumn{10}{|c|}{ Businesses } \\
\hline & \multicolumn{9}{|c|}{ Living places } \\
\hline & \multicolumn{9}{|c|}{ Public Services } \\
\hline
\end{tabular}


The line ordering system illustrates some interesting patterns in the expansion of electricity throughout the three villages (Figure 7). Because access is limited to where transformers occur, expanding access depends on where new transformers are built. Throughout my fieldwork, I learned from members of the community that in order for a new transformer to be considered, at least 50 potential customers must express interest for it to receive government funds. This was also confirmed in an interview with KPLC. Therefore, when a new transformer is installed, lines expand as availability is extended. Proximity analysis conducted on connected households and the first order - or main power line - illustrate that electrification expansion at Mt. Kasigau is currently estimated to be 80 meters on average. In other words, the average grid connection is 80 meters from the main distribution line. Distances between connected households and the main power line were calculated to be a maximum of 580 meters, and a minimum of 1 meter. On average, connected household are 83 meters from the main power line.

When a demand of 50 customers cannot be met, individuals may choose to personally finance the installation of a transformer. We mapped two privately financed transformers at Kasigau. In Jora, a previous county senator financed the installation of one transformer, and in Bungule a person who is known for outsourcing bottled water also financed the installation of one transformer. In both cases, these activities expanded public access to electricity by increasing the available service area. We mapped 21 homes, three businesses and one public service connected within the service area of these two transformers. In contrast, I also encountered a situation in Jora where one home was located within 10 meters of the main power line, however it was not able to connect because it was just outside of the service area. Instead, this home had to wait until the private transformer was installed by the former County Senator to service a personal borehole (Figure 7). Ultimately, availability is determined not only by where transformers are placed, but also by patterns of expansion. 

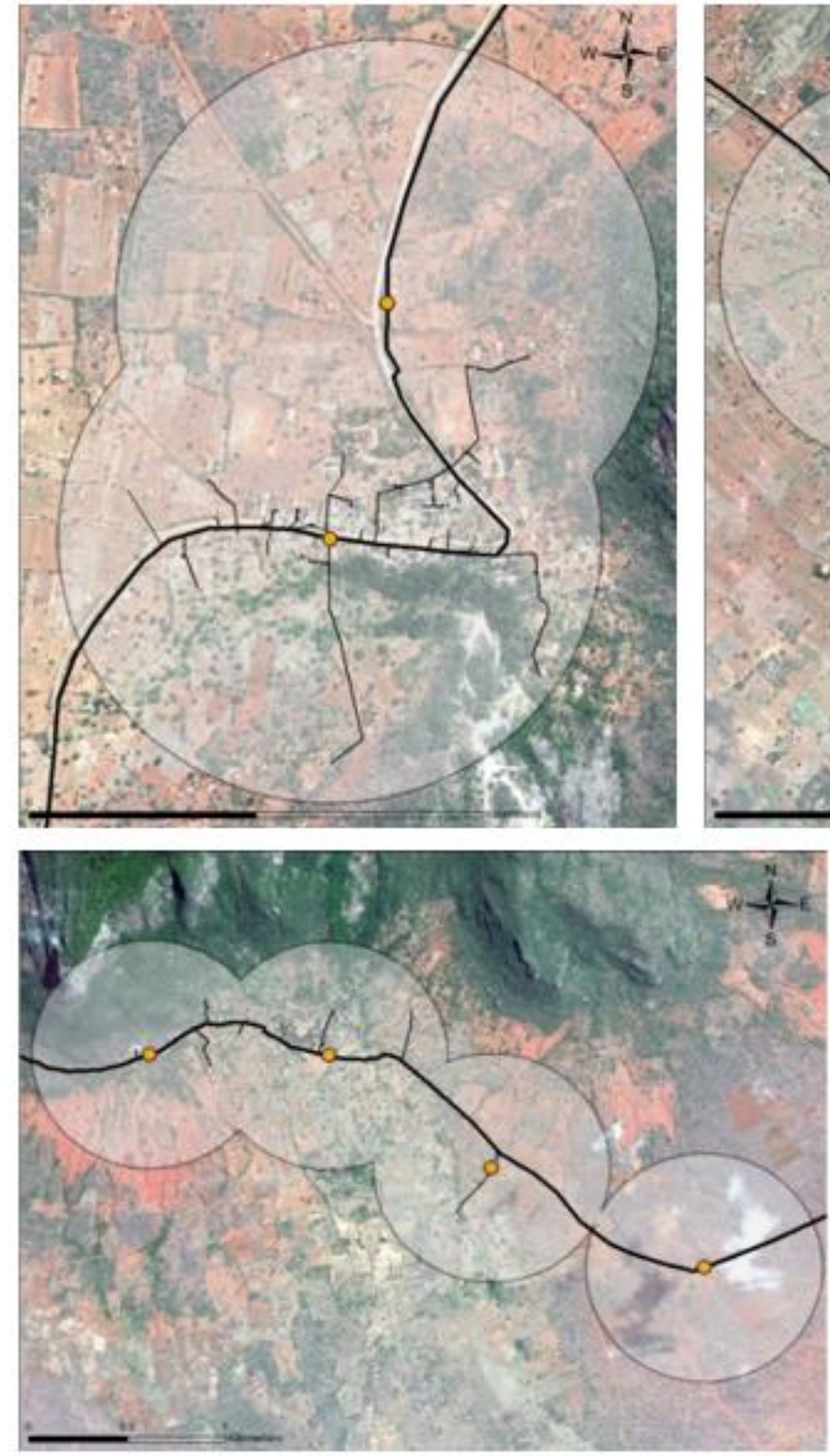

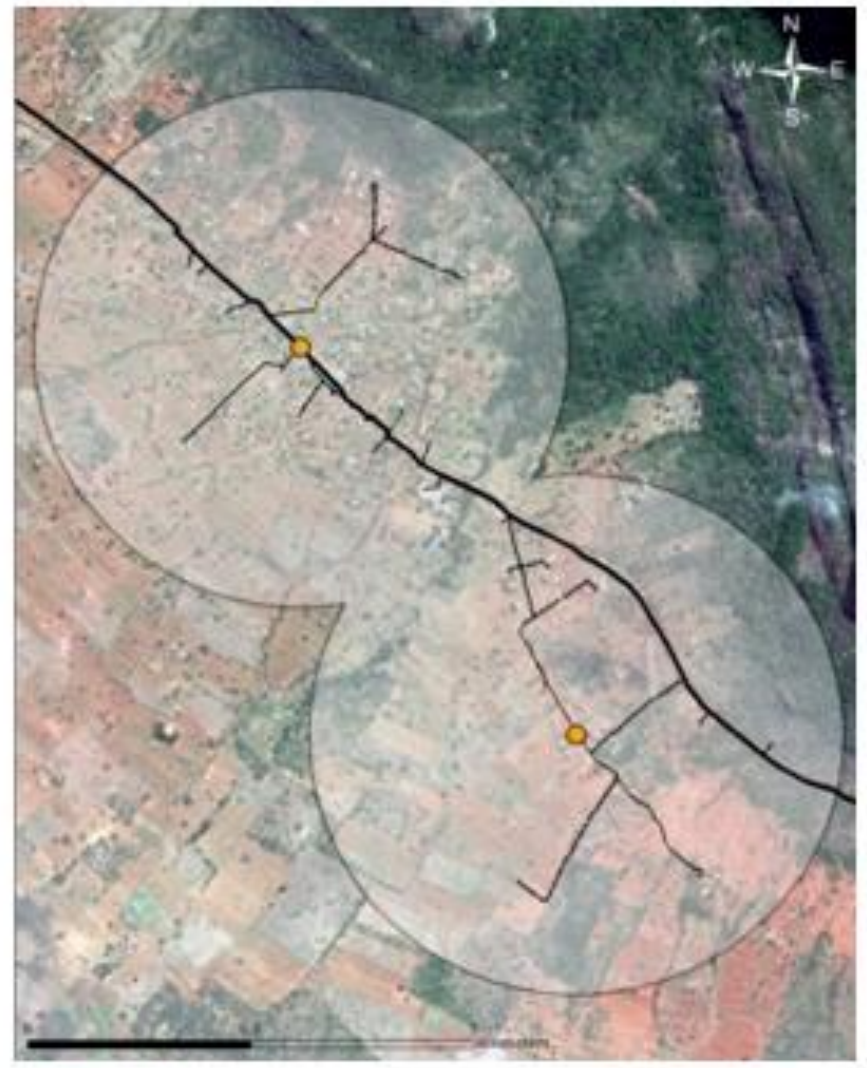

Line Order

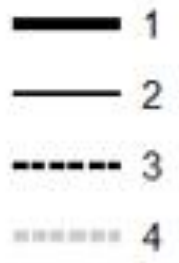

Transformer

Normal

- Large

Transformer Service
Area

Figure 7: A line ordering system, that assigns a value to a power line based on the order in which it was connected from the main distribution line. Note the greater infrastructure, more high order lines, in the Rukanga, where electricity was first introduced. 


\subsection{A Livelihood Analysis of Energy Use}

My second research question sought to identify how residents are meeting their 'electrical' energy needs and how electrification at Mt. Kasigau is influencing energy use activities at the household and community levels. We conducted twenty five interviews among the three villages: 10 in Jora; 10 in Rukanga; and 5 in Bungule. We interviewed 6 men, 12 women and 4 couples in households that varied from one to nine persons (mean= 4.9 people). Additionally, I interviewed a representative from Kenya Power and Lighting Company at their regional office in Voi and a professional power line installer working in the villages who provided further insight on the development intervention.

\subsubsection{Assessing energy needs}

The first interview question focused on how participants meet their 'electrical' energy needs for services such as lighting and phone charging. Fourteen participants responded YES to being connected to the national electrical grid, while eleven responded NO. Among the homes connected to the grid, eight were only utilizing grid energy, six were utilizing both grid electrical and solar power, eight had only solar, and three had no 'electrical' energy source in the home. Solar connections at village homes and in the community were most purposefully used for lighting when grid electrical was not working are not available (Figure 8). Those home that did not have access to grid electric or solar power relied on the use of kerosene and fuelwood as their only sources of light.

The participants who responded YES to having an electrical connection in their home were asked to describe how grid electrical energy serves their needs. Thirteen different uses of electricity were identified with the top three being lighting (93\% of the home interviews), charging their own phones (79\%), and television (64\%) (Figure 9; e.g., Figure 10). Electrical lighting was described as being extremely important with regard to health and education. For example, electric lighting does not emit dangerous fumes like kerosene lamps do,

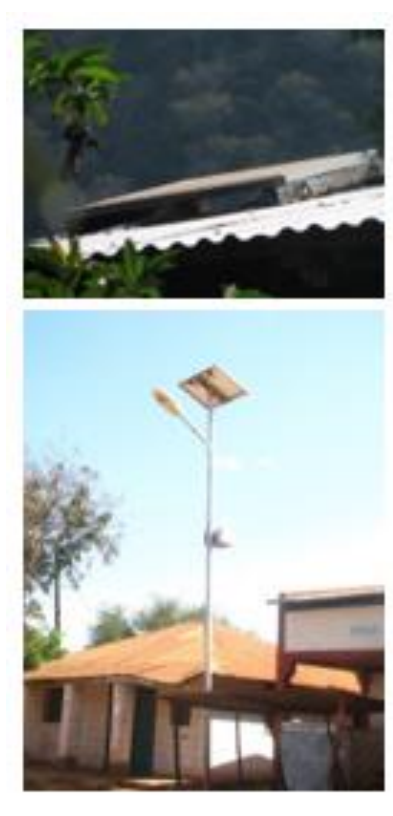

Figure 8: Solar power being utilized in large and small capacities in the household, as well as at the community level for solar security lighting in Rukanga. 
and parents expressed that grid electrical is a large benefit because their children are able to study more efficiently and more safely in the home. Electric radios were popular sources of news and personal entertainment at Mt. Kasigau. For example, one woman described how her electric radio provided an opportunity to listen to music, which she can dance to in her home when she was feeling sad. Small appliances accounted for some electricity use as well, such as electric hot plates used to boil water quickly and electric irons to iron clothes. Although electricity was sometimes used to aid in cooking, traditional methods of wood-burning stoves (jiko) were used in every household I visited (Figure 9).

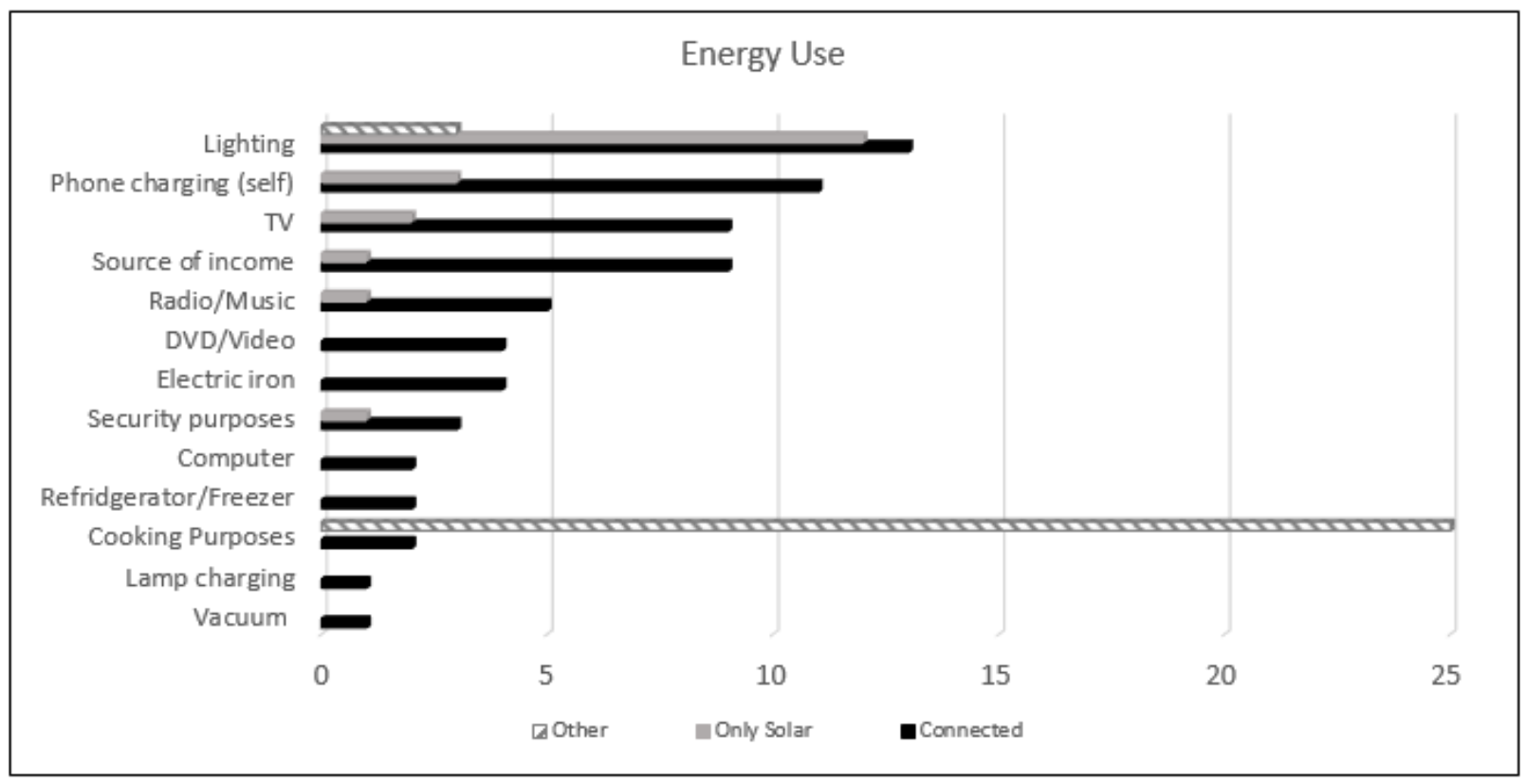

Figure 9: Electrical, solar and 'other' uses of energy described at Mt. Kasigau.

Seven homes used electrical power as a source of income. For example, one man in Jora explained that he is a welder, and invested in electric tools when he gained an electrical connection (Figure 10). A different man in Jora described how he owns two additional buildings in town that he had connected to electricity, which he rents out as a chemist (pharmacy) and a cosmetics store. He explained that the buildings connected to grid electricity are more attractive to renters, making them good for the development of the village center. He mentioned the amount of growth occurring in Rukanga town center, and joked, "If they keep developing, soon they will have traffic lights!" Another popular use of electricity for income was to charge other people's cell phones for a fee. To get a cell phone charged by a neighbor in a home cost between 
10 and $20 \mathrm{Ksh}$, and households that charged phones described charging between one and five phones per day. These respondents earned up to $100 \mathrm{Ksh}$ day in income. Television was also used as a source of income in one home. This household described showing popular football matches when they are aired on television and charging a small fee for people wanting to view the event. In addition, television provides a source of news to households. Finally, one woman explained how she has started selling small solar lamps, called "d.lights" to her friends and neighbors. As a distributer of the lamps, she makes a profit off every lamp sold.
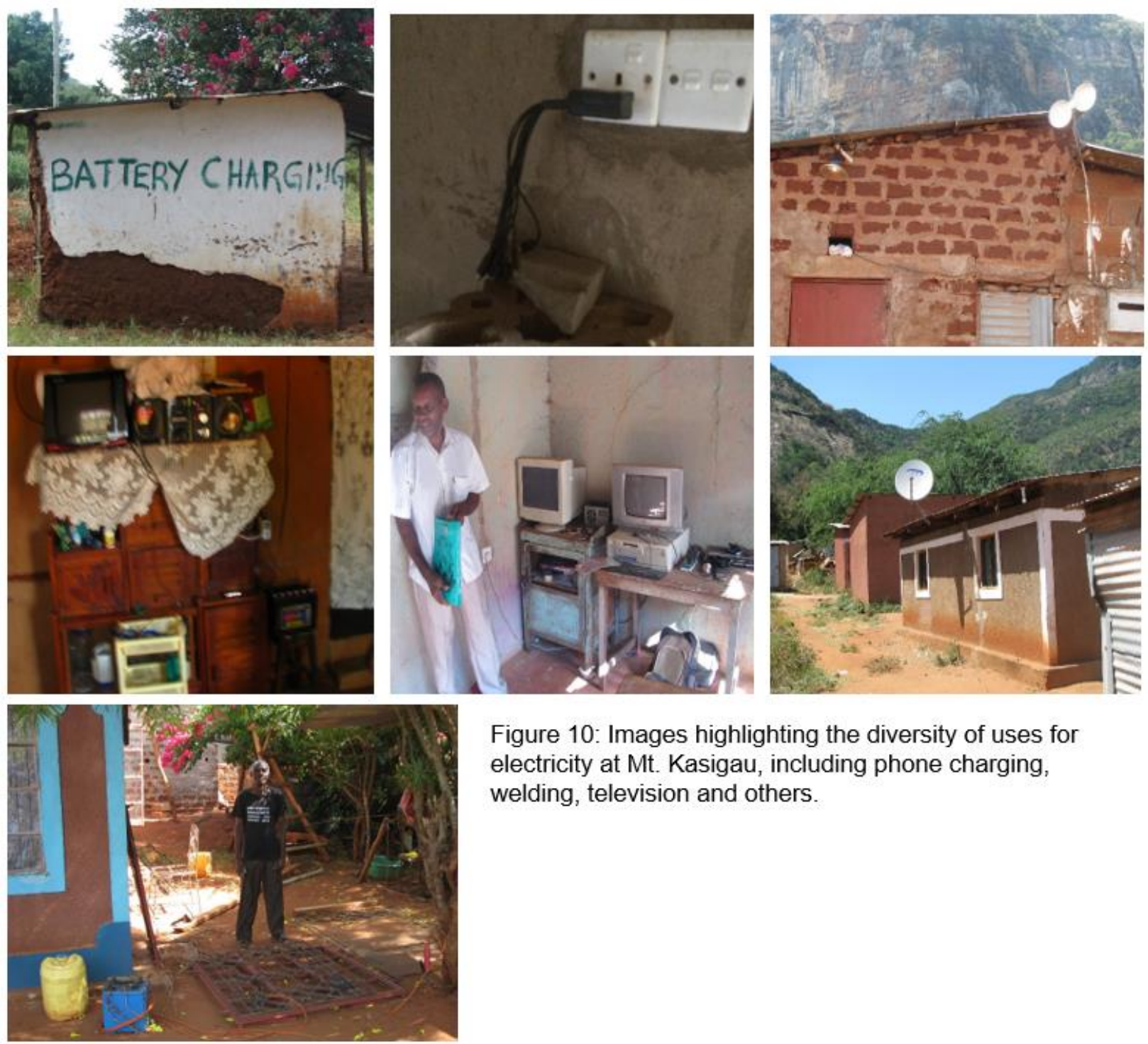

Figure 10: Images highlighting the diversity of uses for electricity at Mt. Kasigau, including phone charging, welding, television and others. 


\subsubsection{Community-level electric energy use}

Participants who responded NO to having electrical connection in their home were asked to describe how their energy needs were influenced by the introduction of electricity to their community. The positive effects of electric and solar power on livelihoods were echoed among the respondents. For example:

"Yes, it did. [Electricity] made me feel more secure, like a part of the rest of the community. Electricity is cheaper - the costs for kerosene are high. Also, while using lanterns and burning wood there is smoke and it is uncomfortable. With electric lights, there is no smoke so it is more comfortable. "- Interview in Jora

One community-level use that was described was charging a cell phone at a charging station in town. Five participants described paying between 15 and $25 \mathrm{Ksh}$ to have a cell phone charged, which was usually at a business in the nearest town center. Another community-level benefit, unique to Rukanga, was security lighting in the town center and at other community areas (schools, churches, etc.). Rukanga utilized both electric and solar power for security lighting (Figure 9), and a number of participants reported that they feel more secure navigating the streets after dark. One home in Bungule that was outside the service range of a transformer described issues with elephants trampling his crops. He suggested that community-level security lighting could potentially help keep elephants out of his gardens. Lighting was also reported to benefit the community schools for educational purposes. In the evenings, I observed students returning to the primary schools to continue studying. I learned that the schools encourage this in order to take advantage of the power while it is working. Finally, participants reported that they believe grid electricity provides increased opportunities for development in Rukanga. Two households without an electrical connection in their home described how they envy businesses which rely on electricity, and that they often consider the prospect of being able to run a business (hair solon) with electric equipment.

\subsubsection{Household electrification costs}

I was informed in an interview with KPLC that national energy prices are maintained by the Energy Regulatory Commission (ERC) in Kenya. In this capacity, the ERC is responsible for addressing retail and "bulk" energy tariffs and frameworks and regulating electrical energy 
generation. KPLC explained that domestic tariffs operate on a sliding scale. For example, preend users (i.e. the first 50 customers to connect to a new transformer) are offered cheaper prices, whereas end users are required to pay a higher price. Additionally, these domestic consumer tariffs differ from business and commercial tariffs, which operate on a flat scale.

Participants who invested in an electrical connection reported spending between 29,000 and 200,000 Ksh (mean = Ksh 43,294) on their systems. Costs include a connection fee, plus wiring to and within their home. Accordingly, costs increased with distance to the main distribution power line (first order line; Figure 11). However, costs also varied in relation to how the energy source was distributed and used in the home. For example, one home in Bungule represents a distinct 'outlier.' This home is owned by a woman who previously lived in Germany for an extended period of time, and had an extensive system of wiring to serve electrical needs in the home. Respondents reported connection fees ranging from 17,000 to 35,000 Ksh (mean = $29,500 \mathrm{Ksh}$ ) and wiring costs wiring costs, participants described expenses ranging from 10,000 to $20,000 \mathrm{Ksh}$ $($ mean $=14,625 \mathrm{Ksh})$. Although my research took place during the first phase of the Last Mile Connectivity Project (LMCP), which offered lower-costing connections to rural homes in specified areas, the transformers at Mt. Kasigau

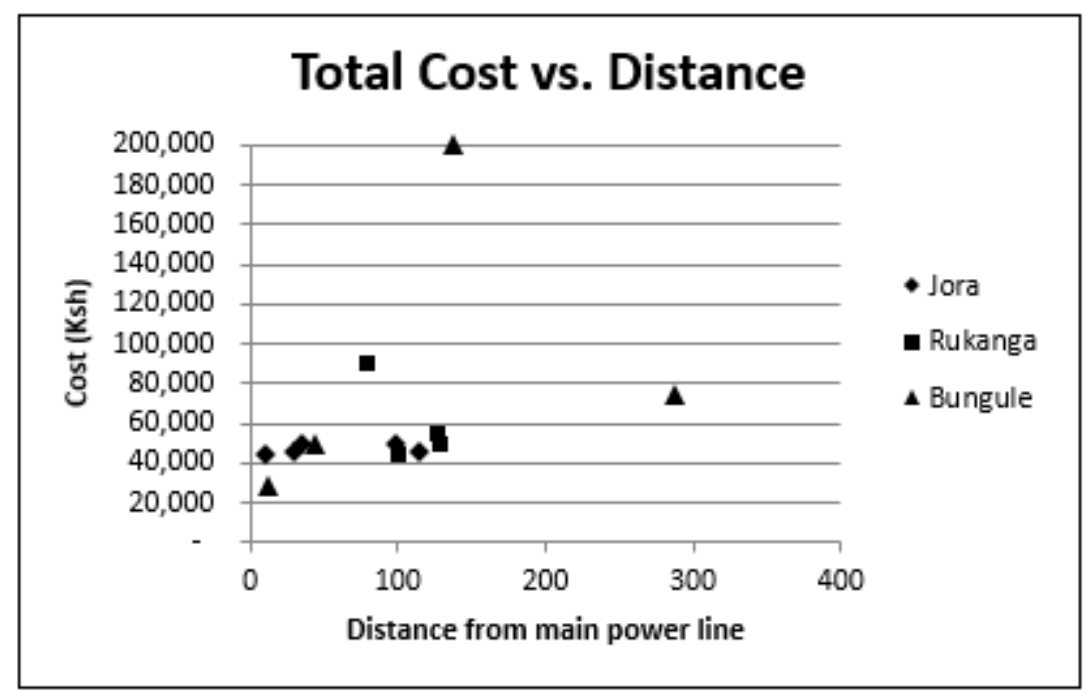

Figure 11: An illustrations of the relationship between cost and distance from the main power line reported at Mt. Kasigau. were not affected by this policy (KPLC, 2016b).

Monthly payments for grid electricity at nine homes ranged from $200 \mathrm{Ksh}$ to 1,600 Ksh $($ mean $=887 \mathrm{Ksh})$, and depended largely on the size of the home, number of appliances being used, and the reliability of the supply. Reported costs show a positive correlation to the number of described uses and costs (Figure 11). One participant described lowering costs by using 
different devices at different times. The family agreed to turn off appliances such as the TV and radio when it gets dark, so that the children can instead use the light for studying in their home. In contrast, highest costs were reported at one home that included a refrigerator among the appliances, which was used to keep juices.

\subsubsection{Energy reliability}

Eleven respondents expressed that the availability of grid electricity is "not reliable", while only one respondent reported electricity as "reliable." Power generally goes out every week for between two and seven days at a time. Only one respondent expressed that this was not a problem for her household, while all others described this as either a slight inconvenience or a major problem. For example, one man who invested in electric welding tools explained that his livelihood is affected when the power is out because he cannot work:

"I applied for electricity, and I was approved. I chose to do this because I had no other option. I use the electricity for my welding business, but it is not very reliable. Sometimes it goes out for three or four days at a time. If it is off, I cannot work because my tools are electric, and I have no income. Electricity determines if I can work or not." - Jora interview *translated from Swahili to English

The respondents also explained that the loss or temporary absence of electricity is also detrimental to the community. Businesses that rely on grid electricity, such as phone charging or electric cash registers, cannot operate, and security lighting is not available when the power is out. Another issue with raised with power outages in the household was safety. For example, one home in Jora explained that "sometimes the power goes out without warning, which is dangerous." I experienced instances where the power went out in the middle of cooking a meal with a hot jiko (stove), and everyone in the household had to be very careful to navigate the room to light candles, etc. This issue leads to burns being a common injury.

Respondents also reported poor communication between suppliers and customers. One person explained that it is difficult for residents at Mt. Kasigau to plan for electrical outages, because "[we] never know when the power will go out, or how long it will be out for" (Jora). This person explained that they believe that this is caused by a lack of maintenance on the infrastructure. Additionally, they explained that in a town or a city, there are often 
announcements on television when there is scheduled maintenance being planned so that people are aware that the power will be out. However, rural people often do not get these messages. Environmental factors, such as rain, also affects the reliability of electricity.

The reliability of alternative sources, such as solar, was also discussed in the interviews. Homes that had access to both electricity and solar were not affected as strongly by power outages because they were able to rely on solar lighting at night if electrical lights were not an option. Homes that had access to only grid electricity did not have this option. Generally homes with access to solar power described more "trust" in their systems because solar power is more reliable. Only one participant with access to solar described it as being unreliable, saying; "solar is not reliable. When there is no sun, there is no power" (Rukanga). Generally, solar power was praised for being reliable, and for not requiring a monthly fee. However, it was described as being hindering because of the large initial investment required, and the limitations on potential uses. Overall, despite electricity being described as being "unreliable," most (8) participants who were not connected expressed that they would still invest in grid electricity if the opportunity arose.

I conducted an independent study project that applied raster analysis techniques in GIS which identified a considerable potential for utilizing solar power at the household level at Mt. Kasigau by determining incoming solar radiation values on a high-resolution $(1.63 \mathrm{~m} / \mathrm{pixel})$ World View-2 satellite image. In 2015, incoming solar radiation value was determined to be 3.7 $\mathrm{kWH} / \mathrm{m}^{2} /$ day. This number represents the number of peak sun hours per day. A solar cell's maximum output, or 'peak power' (Wp), is the amount of energy it can provide with regard to the amount of incoming solar radiation available. An average-sized solar system in rural Kenya is $38 \mathrm{Wp}$ (Akers and Kammen 1996). Given $3.7 \mathrm{kWH} / \mathrm{m}^{2} /$ day at Mt. Kasigau, a $38 \mathrm{Wp}$ solar system could provide 140.6 watt hours per day (WH/day), which could power a 10 watt lightbulb for about 14 hours. 


\section{CHAPTER SIX}

\section{Discussion and Conclusion}

Geographic research at the intersection between development critiques and political ecology questions a potential disconnect between extra-local development initiatives and local livelihoods (Neumann, 2005; Robbins, 2012; Watts, 2015). Kenya, under its Vision 2020 for sustainable development, is expanding the national electric grid to many rural areas, potentially introducing electricity as a process and effect on local livelihoods (GOK, 2007; 2016). By assessing the introduction of electricity at Mt. Kasigau, I investigated how the development intervention is perceived and acted upon by local communities and individual residents. Working with community residents in three villages, the study examined how electricity is spatially mapped and narrates local realities to show how the introduction of electricity is affecting livelihoods. The research employed a mixed methods approach, including participatory GIS (PGIS) to map and analyze the spatial occurrences of the electric grid, and semi-structured interviews to gain local perspectives on the processes of community and household-level electrification. Results indicate that mapping the local infrastructure can lend vital context to the process and outcomes of electrification, and that local perceptions of the introduction of electricity are clearly positive at Mt. Kasigau.

\subsection{Electrical Development as Process and Outcome}

Electrification in Kenya is inherently political and by process a development intervention. Extra-local development has the ability to facilitate dynamic changes in local livelihoods at the rural scale (Robbins, 2012). The inherent power relations that exist between those who control the development process (extra-local) and those whose lives are affected by "the project" (local) can produce a new kind of political engagement that invokes changes in the ways that resources can be utilized (Robbins, 2012). Development as a process is influenced by political economic factors, which may or may not have a positive influence on lives. Despite a somewhat turbulent history, more recent progress in development discourse and epistemologies provide a more inclusive examination of process and effect (Misturelli and Heffernan, 2010). Accordingly, a study of electrification as development includes the assessment of material benefits but also the non-material benefits, such as a more enhanced allocation of time and livelihood-related benefits (Toman and Jemelkova, 2002). 


\subsubsection{Availability, accessibility and the use of electricity}

Relationships among the concepts of availability, accessibility and utilization are hierarchical with regard to electrification. Electric energy is made available when it is physically introduced to a community, is accessible only if available and can be afforded by customers, and can be utilized to diversify livelihoods in the home or community once access is secured. However, the literature is confusing regarding the relationship between these terms; it is difficult to find clear distinctions being made between the concepts of energy availability and accessibility. For example, both the International Energy Agency (IEA) and United Nations Development Programme (UNDP) use circular definitions for the respective terms; "energy access - a household having access to electricity and to a relatively clean, safe means of cooking" (IEA, 2016); "energy availability - energy source availability and ease of access as part of local resources" (UNDP, 2017). I chose to define electrical energy availability as the physical presence of an electric grid infrastructure, however I argue that there can be different levels of availability. If an electrical supply and a transformer are present, then electric grid energy is available. However, my data show that the ease of acquiring a physical connection can be influenced by local politics, planning and decision making - not just cost. The bottom line is that although electric grid energy has been made available at Mt. Kasigau, it is more available to some than it is to others. The study defines electrical energy accessibility" as the ability of a household to afford electrical energy services, and defines utilization as the ability of households to use energy in different ways. My research presents a further consideration of the concept of electric grid energy availability by providing examples of cases where electric energy was more available to some homes, and less to others, despite being accessible in both cases. This work compliments studies (Bazilian et al., 2012; Nussbaumer et al., 2012; Parshall et al., 2012; Sanoh et al., 2012; Winkler et al., 2011) that consider energy availability and accessibility in relation to cost and utilization in developing places. Ultimately, electrification is not solely determined by the presence of an electrical transformer, but is also by local factors that influence availability and accessibility. Lee et al. (2016) suggest that even under ideal circumstances for rural electrification (high population density and extensive grid coverage), electrification rates remain low if the considerations of the local context are not made. 


\subsection{Electrification's diversification effect on livelihoods}

Sustainable livelihood development should increase the ability of an individual to lead a meaningful life (Nussbaum and Sen, 1993; Robeyns, 2006). At Mt. Kasigau, the extra-local introduction of electricity gives people new opportunities to meet their energy needs in a variety of ways that can be combined for a more diversified. My study shows that electrification as process and outcome is supported by its direct influence on availability, accessibility (or affordability), and reliability — even though they vary significantly for the residents. Despite issues of poor availability, accessibility and reliability, electric energy at Mt. Kasigau offers new opportunities for the community and households to meet their energy needs. Having access to some electric energy is better than having no electric energy because new opportunities to achieve a capable livelihood are introduced at the household and community level. Having this option as a choice improves these opportunities.

Local perceptions at Mt. Kasigau support research showing how access to electrical energy diversifies livelihoods (Bazilian et al., 2012; Modi et al., 2005; Winkler et al., 2010). Electrification at the rural scale is considered a "choice-based" livelihood diversification method (Ellis, 2000). This method, as opposed to "necessity-based" diversification, highlights the fact that no one is forced to connect to the national grid at Mt. Kasigau. Instead, the introduction of grid electric is giving people the choice to access electrical energy. Participants at Mt. Kasigau illustrated how they are building their livelihoods around this choice. Ellis $(2000,74)$ describes determinants of livelihood diversifications, which depict rural households taking a more longterm view on livelihood security, and therefore carefully (almost suspiciously) considering investments. This is particularly true for asset strategies; investing in order to enhance future livelihood prospects. In this sense, an investment in grid electric can be seen as influencing both material assets (i.e. good lighting) and non-material assets (i.e. perceptions of safety in the household and community).

There are limits to which electric energy was described as influencing livelihood diversification. In the household, electric energy was described as having major influences over things like more efficient and safe lighting, cell phone charging, television and other sources of news, and being utilized as a source of income. Electric energy did not, however, seem to influence a more traditional method of using fuelwood for cooking purposes. Even more wealthy 
homes that had expensive electrical systems in their homes utilized fuelwood for cooking. This is most likely due to the fact that using electric energy for cooking is very expensive, and would make it unaffordable even to the wealthy. Fuelwood is a much cheaper and more logical strategy for cooking.

There is no doubt that people perceive electric energy as offering positive effects, especially at the community level. Referring to the five types of capital which form livelihoods (Ellis, 2000 in Chapters 1 and 2), electricity was recognized as influencing physical capital in the form of infrastructure, human capital in the form of education, financial capital in the form of saving money over time, and social capital in the form of building stronger community networks. These capitals characterize livelihoods (Carr 2013; Chambers, 1997; Ellis 2000), and when they are allowed to be sustained over time without compromising needs in the future, they are considered sustainable livelihoods (Chambers, 1997). The distinction between use in a private home and use at the community scale (business, public service) is clear - although unconnected homes express that they desire connections in their home, they also clearly express that they benefit from electrical connections at the community scale though schools, businesses, health care, security, and overall community growth. This supports important foundational theories that energy insecurities affect livelihoods, and that the introduction of electric grid energy has the potential to influence how people meet their energy needs (Modi et al., 2005; Sanoh et al., 2012; Showers, 2011)

\subsubsection{Cost and reliability}

Rural electrification projects struggle with issues of cost and reliability (Adkins et al., 2012; Davidson and Stanford, 2004; Parshall et al., 2009; Showers, 2011; Winkler, 2011); a critique also supported by the respondents at Mt. Kasigau. Affordability is a politicized concept, and refers not only to if a household can afford to connect, but also if they are able to afford to use the service after they have connected (Winkler et al,. 2011). This 'cost to connect versus cost to use' was a major theme which emerged from the work. The Daily Nation, a credible national newspaper in Kenya, highlight in an article that questions weather introducing electricity to homes who are not able to afford food and water, let alone electricity fees, is logical? If a home gains a connection, but cannot afford to use its connection, is it electrified? Similar questions arose at Mt. Kasigau. Unconnected households at Mt. Kasigau described struggling to afford an 
electrical connection due to the large initial investment, and connected households recounted difficulty in saving enough money to afford their connection and monthly payments. Participants also described electricity as being unreliable both in service quality and infrastructure quality. However, participants who were not connected to the grid expressed that cost, not reliability, was the driving factor behind why they were not connected to the grid. In other words, although they recognized the poor reliability, they expressed that they would still connect to the national grid if they were able to afford it.

\subsection{A critique and limitations of the research}

In consideration of the ethical obligations of participatory research, to be wholly effective a project that utilizes participatory methods must ask of itself, "how participatory?" Smith (2010) highlights the fact that 'keeping ties' with the communities that were involved in the research is an important aspect of participatory research. In order for my research to come full circle, I will provide the communities of Mt. Kasigau with a written synthesis of my work, detailed and enlarged maps which illustrate the results of the work, and a personalized message to my research assistant and participants. Additionally, I would like to provide my spatial dataset to organizations involved with energy planning and distribution, with the hope that it will aid in future development of sustainable livelihoods at Mt. Kasigau.

Finally, it was the goal of this research to identify the exact chronology of the electrification infrastructure at Mt. Kasigau, however, this task was not entirely successful. Acquiring exact dates of installation was not possible in the timeframe for the study. The research groups attempted to speak to home and business owners who had connected to the grid in order to identify when they did so, but most often they were not available to speak, or could not recall the exact date/year that they did so. Additionally, dates of installation for transformers are kept by the power distributer Kenya Power and Lighting Company, who declined to provide this information.

\section{$\underline{6.4 \text { Conclusion }}$}

The goal of this research was to produce a critique electrification as process and outcome. Locally-validated narratives counter a negative view of this development intervention and its effect on livelihoods. Connections are available to only a small portion of the population, are 
expensive and thereby inaccessible, and are consistently viewed as unreliable. Despite these limitations, the study findings showed a clear consensus on its positive influence over livelihoods at Mt. Kasigau. Electric energy diversifies livelihoods at the household level by introducing electric lighting, cell phone charging, and the opportunity to make use of other electric appliances, and at the community level by offering more reliable services related to health and education, and by ensuring a sense of safety through the introduction of security lighting. These community contributions offset individual access as a criteria for benefit - one does not necessarily need an individual electrical connected to benefit from the introduction of electric energy in a community. Moreover, electric energy offers new opportunities for people to combine energy need strategies more effectively, making them more capable to live a diversified life. These perceptions were narrated by local people, and spatially validated through participatory mapping exercises. The spatial representation of these realities lends important context to relationships among resource availability, accessibility and utilization in a rural Kenyan setting. 


\section{REFERENCES}

Adams, W. (2002). Green Development: Environment and Sustainability in the Third Word. London: Routledge.

Adkins, E., K. Oppelstrup and V. Modi. (2012) "Rural Household Energy Consumption in the Millennium Villages in Sub-Saharan Africa.” Energy for sustainable development 16(3): 249-259.

Ackers, R. and D. Kammen. (1996). “The quiet (energy) revolution”. Energy Policy. 1:24: 81111.

Ashby, J., J. Sanz, E. Knapp and A. Imbach. (1999). “CIAT's Research on Hillside Environments in Central America.” Mountain Research and Development 19(3): 241250.

Bagchi, D.K, P. Blaikie, H. Cameron, M. Chattopadhyay, N. Gyawali and D. Seddon. (1998). "Conceptual and Methodological Challenges in the Study of Livelihood Trajectories: Case-studies in Eastern India and Western Nepal." Journal of International Development 10: $453-468$

Batty, M. (2006). "Using Geographical Information Systems.” In Key Methods in Geography. Clifford, N. and G. Valentine, ed. London: Sage: 409-423.

Bazilian, M., P. Nussbaumer, C. Eibs-Singer, A. Brew-Hammond, V. Modi, B. Sovacool, V. Ramana and P. Aqrawi. (2012). "Improving Access to Modern Energy Services: Insights from Case Studies." The Electricity Journal 25(1): 93-114.

Bernard, R. (2000). Social Research Methods - Qualitative and Quantitative Approaches. Thousand Oaks: Sage Publications.

Bery, R. (1995). 'Media Ethics: No Magic Solutions.' In Power, Process and Participation: Tools for Change. Slocum, R., L. Wichhart, D. Rocheleau, and B. Thomas-Slater, ed. London: Intermediate Technology Publications. 41-50.

Blaikie, P. (1985). The political Economy of Soil Erosion in Developing Countries. Longman, 1985.

Blaikie, P. (2008). "Epilogue: Towards a Future for Political Ecology that Works." Geoforum 39 (2): 765-772.

Blaikie, P. and H. Brookfield. (1987). Land Degradation and Society. London: Routledge.

Bradshaw, M. and E. Stratford. (2000). “Qualitative Research Design and Rigor.” In Qualitative Research Methods in Human Geography. Hay, I., ed. New York: Oxford University Press: 37-49.

Breitbart, M. (2006). "Participatory Research Methods" In Key Methods in Geography, eds. Clifford, N. and G. Valentine, pp. 161-178. London: Sage Publications Ltd

Cameron, J. (2000). "Focusing on the Focus Group." In Qualitative Research Methods in Human Geography. Hay, I., ed. New York: Oxford University Press. 83-102. 
Carr, E. (2005). "Development and the Household: Missing the Point?" GeoJournal 1: 71-83.

Carr, E. (2013). "Livelihoods as Intimate Government: Reframing the Logic of Livelihoods for Development." Third World Quarterly 43 (1): 77-108.

Chambers, R. (1988). Sustainable Livelihoods, Environment and Development: Putting Poor Rural People First. Institute of Development Studies: Discussion paper 296.

Chambers, R. (1994). “The Origins and Practice of Participatory Rural Appraisal.” World Development 22(7): 953-969.

Chambers, R. (1997). Whose Reality Counts: Putting the First Last. London: Intermediate Technology Publications.

Cope, M and S. Elwood, ed. (2009). Qualitative GIS: A Mixed Methods Approach. London: Sage Publications.

Corbett, J. and G. Rambaldi. (2009). "Geographic Information Technologies, Local Knowledge, and Change." In Qualitative GIS: A Mixed Methods Approach. London: Sage Publications. 75-92.

Cornwall, A. and C. Nyamu-Musembi.( 2004). "Putting the 'Rights-Based Approach' to Development into Perspective.” Third World Quarterly 25(8): 1415-1437.

Davidson, O. and Stanford, M. (2004). "Electricity Access for the Poor: A Study of South Africa and Zimbabwe." Energy for Sustainable Development 8(4): 26-40.

Dunn, Kevin. (2000). "Interviewing” In Qualitative Research Methods in Human Geography. Hay, I., ed. New York: Oxford University Press. 50-81.

Ellis, F. (2000). Rural Livelihoods and Diversity in Developing Countries. New York: Oxford University Press.

ESI Africa. (2016). “Kenya: Electricity access stats at 56\%”. Africa's Power Journal. Accessed On April 14, 2017 At: https://www.esi-africa.com/news/kenya-electricity-access-stats-at$56 /$

Escobar, A. (1992). "Grassroots approaches and alternative politics in the Third World.” Futures 411-436

Escobar, A. (1995). Encountering Development. Princeton: Princeton University Press.

Ferguson, J. (1994). The Anti-politics Machine: 'Development' and Bureaucratic Power in Lesotho Minneapolis: University of Minnesota Press.

Flicker, S., R. Travers, A. Guta, S. McDonald, A. Meagher. (2007). "Ethical Dilemmas in Community-Based Participatory Research: Recommendations for Institutional Review Boards." Journal of Urban Health 84(4): 478-493.

Fukuda-Parr, S. (2011). "Theory and Policy in International Development: Human Development and Capability Approach and the Millennium Development Goals." International Studies Review 13: 122-132. 
Goss, J. and t. Leinbach. (1996). "Focus Groups as Alternative Research Practice: Experience with Transmigrants in Indonesia." Area 28(2): 115-123.

GOK [Government of Kenya]. (2007). “Kenya Vision 2030: The Popular Version”.

GOK [Government of Kenya]. (2016). "Progress (2016 march): Energy Generation and Distribution." Accessed on April 17, 2017 at: http://www.vision2030.go.ke/493/progress2016-march-energy-generation-distribution/

Hay, I. (2006). "Ethical Practices in Geographical Research.” In Key Methods in Geography. Clifford, N. and G. Valentine, ed. London: Sage Publications Ltd. 37-54

IAEA [International Atomic Energy Agency]. (2005). "Energy Indicators for Sustainable Development: Guidelines and Methodologies". International Atomic Energy Agency. Accesses on April 15 ${ }^{\text {th }}, 2017$ at: http://www.unosd.org/content/documents/1237Pub1222_web\%20EISD.pdf

IEA [International Energy Agency]. (2016). “Defining and modelling energy access.” World Energy Outlook. Accessed on April 15 th 2017 at: http://www.worldenergyoutlook.org/resources/energydevelopment/definingandmodelling energyaccess/

Kalibo, H. and K. Medley. (2007). "Participatory Resource Mapping for Adaptive Collaborative Management at Mt. Kasigau, Kenya." Landscape and Urban Planning 82(3): 145-158

Kearns, R. (2000). "Being There: Research through Observing and Participating.” In Qualitative Research Methods in Human Geography. Hay, I., ed. New York: Oxford University Press. 103-121.

KMEP [Kenya Ministry of Energy and Petroleum, Republic of Kenya]. (2015). "Draft: National Energy and Petroleum Policy." Internet. Accessed April $21^{\text {st }} 2016$ at http://www.erc.go.ke/images/docs/National_Energy_Petroleum_Policy_August_2015.pdf

Kenya National Bureau of Statistics, Republic of Kenya. (2014). "Economic Survey 2014". Internet. Accessed April 21 2016 at http://www.knbs.or.ke/index.php?option=com_phocadownload\&view=category\&id=107 $\&$ Itemid=1181

KNBS [Kenya National Bureau of Statistics], Republic of Kenya. (2017). "Economic Survey 2017'. Internet. Accessed April 21 2017 at: http://www.knbs.or.ke/index.php?option=com_phocadownload\&view=category\&id=107 $\&$ Itemid $=1181$

King, B. (2002). "Towards a Participatory GIS: Evaluating Case Studies of Participatory Rural Appraisal and GIS in the Developing World." Cartography and Geographic Information Science 29(1): 43-52.

King, B. (2011). "Spatialising Livelihoods: Resource Access and Livelihood Spaces in South Africa." Transactions of the Institute of British Geographers 36(2): 297-313. 
Kniggee, M and M. Cope. (2009). "Grounded Visualization and Scale: A Recursive Analysis of Community Spaces” In Qualitative GIS: A Mixed Methods Approach. Cope, M. and S. Elwood, ed. London: Sage Publication. 95-114.

Knight, C. G. (1992). “Geography’s Worlds.” In Geography’s Inner Worlds, eds. R. F. Abler, M. Marcus and J. Olson, 9-26. New Brunswick, NJ: Rutgers University Press.

KPLCa [Kenya Power and Lighting Company]. (2016). "Electrification Project". Accessed on April 15, 2017 at: http://www.kplc.co.ke/content/item/1119/electrification-project-

KPLCb [Kenya Power and Lighting Company]. (2016). "Last Mile Connectivity Program Q\&A”. Accessed on April 15, 2017 at: http://www.kplc.co.ke/content/item/1694/lastmile-connectivity-program-q---a

Laurier, E. (2006). "Participant Observation." In Key Methods in Geography. Clifford, N. and G. Valentine, ed. London: Sage Publications Ltd. 133-148

Lee, K., E. Brewer, C. Christiano, F. Meyo, E. Miguel, M.Podolsky, J. Rosa, \& C. Wolfram. (2016). "Electrification for "Under Grid" households in Rural Kenya." Development Engineering 1: 26-35.

Longhurst, R. (2006). “Semi-structured Interviews and Focus Groups.” In Key Methods in Geography Clifford, N. and G. Valentine, ed. London: Sage Publications Ltd. 117-132.

Mabogunje, A. (1981). The Development Process: A Spatial Perspective. New York: Holmes and Meier Publishers Inc.

Malczewski, J. (1999). GIS and Multicriteria Decision Analysis. New York: John Wiley \& Sons, Inc.

Medley, K.E., J.K. Maingi, K. Maingi and M. Henkin. (In Press). "Embedded Histories and Biogeographic Interpretations of Forest Diversity at Mt. Kasigau, Kenya”. African Geographical Review.

Misturelli, F. and C. Heffernan. (2010). "The Concept of Poverty: A Synchronic Perspective.” Progress in Development Studies 10(1): 35-58.

Mitchell, A. (2012). The ESRI Guide to GIS Analysis. Redlands, CA: Esri Press.

Modi, V., S. McDade, D. Lallement and J. Saghir. (2005). "Energy Services for the Millennium Development Goals." Energy services for the millennium development goals. World Bank.

Monteiro, C., I. Ramirez-Rosando, V. Miranda, P. Zorzano-Santamaria, E. Garcia-Garrido, and L. Fernandez-Jimwnwz. (2005). "GIS Spatial Analysis Applied to Electric Line Routing Optimization.” IEEE Transactions on Power Delivery 20(2): 934-942.

Moriarty, P. (2002). "Sustainable Livelihoods Approaches: An Explanation.” Water and Livelihoods 22(3): 4-6

Nerini, F., M. Howells, M. Bazilian and M. Gomez. (2014). "Rural Electrification Options in the Brazilian Amazon: A Multi-Criteria Analysis.” Energy for Sustainable Development 20: $36-48$. 
Neumann, R. (2005). Making Political Ecology. New York: Oxford University Press.

Nussbaum, M. and A. Sen. (1993). The Quality of Life. New York: Oxford University Press.

Nussbaumer, P., M. Bazilian and V. Modi. (2012). "Measuring energy poverty: Focusing on What Matters." Renewable and Sustainable Energy Reviews 16(1): 231-243.

Otuki, Neville. (2016). "Kenya's Power Imports From Uganda Now Rise 32 per cents”. The East African. September. Accessed on April 13 $3^{\text {th }}, 2017$ At: http://www.theeastafrican.co.ke/business/Kenya-power-imports-from-Uganda-now-rise32-per-cent-/2560-3371112-12t3q0e/index.html

Parliament of Kenya. (2006). "Energy Act." Accessed Electronically on March 2 ${ }^{\text {nd }}, 2017$ at: http://www.erc.go.ke/images/Regulations/energy.pdf

Parshall, L., D. Pillai, S. Mohan, A. Sanoh and V. Modi. (2009). "National Electricity Planning in Setting with Low Pre-existing Grid Coverage: Development of a Spatial Model and Case Study of Kenya." Energy Policy 37(6): 2395-2410.

Peet, R. and E. Hartwick. (2009). Theories of development: Contentions, arguments, alternatives. Guilford Publications.

Peet, R. and M. Watts, eds. (2004). Liberation Ecologies: Environment, Development, Social Movements. New York: Routledge.

Peluso, N. (1995). "Whose Woods are These? Counter-Mapping Forest Territories in Kalimantan, Indonesia." Antipode 27(4): 383-406.

Pred, Allan and M.J. Watts. (1992). Reworking Modernity: Capitalisms and Symbolic Discontent. New Brunswick: Rutgers, The State University.

Power, M. (2003). Rethinking Development Geographies. New York: Routledge.

Rhoads, L. Bruce and D. Wilson. (2010). "Observing Our World” In Research Methods In Geography. Gomez, B. and J.P. Jones III, ed. 26-27.

Rice, S. (2006). "Sampling in Geography." In Key Methods in Geography Clifford, N and G. Valentine, ed. London: Sage Publications Ltd. 223-248.

Rist, Gilbert. (1997). The History of Development. New York: Zed Books

Robbins, P. and K. Monroe Bishop. (2008). "There and Back Again: Epiphany, Disillusionment, and Rediscovery in Political Ecology." Geoforum 39(2): 747-755

Robbins, P. (2003). "Beyond Ground Truth: GIS and the Environmental Knowledge of Herders, Professional Foresters, and Other Traditional Communities." Human Ecology 31(2): 233253.

Robbins, P. (2011). Political Ecology: A Critical Introduction. John Wiley \& Sons.

Robeyns, I. (2006). “The Capability Approach in Practice.” The Journal of Political Philosophy 14 (3): 351-376. 
Rocheleau, D. (1995). "Maps, Numbers, Text, and Context: Mixing Methods in Feminist Political Ecology" Professional Geographer 47(4): 458-466

Rocheleau, D. (2007). "Political Ecology in the Key of Policy: From Chains of Explanation to Webs of Relations." Geoforum 39(2): 716-727.

Sanoh, A., L. Parshall, O. Fall-Sarr, S. Kum and V. Modi. (2012). "Local and National Electricity Planning in Senegal: Scenarios and Policies.” Energy for Sustainable Development 16(1): 13-25.

Scoones, I. (2009). "Livelihood Perspectives and Rural Development." The Journal of Peasant Studies 36(1): 171-196.

Secor, A. (2010). "Social Surveys, Interviews, and Focus Groups." In Research Methods in Geography. Gomez, B. and J. Jones III, ed. 194-205

Showers, K. (2011). "Electrifying Africa: An Environmental History with Policy Manipulations.” Geogrfiska Annaler: Series B, Human Geography 93(3): 193-221.

Slocum, R., L. Wichhart, D. Rocheleau and B. Thomas-Slayter, eds. (1995). Power, Process and Participation: Tools for Change. London: Intermediate Technology Publications Ltd.

Smith, F. (2006). "Working in Different Cultures." In Key Methods in Geography. Clifford, N. and G. Valentine, eds. London: Sage Publications Ltd. 179-193.

Smith, D. (2010). “The Politics and Ethics of Research” In Research Methods in Geography. Gomez, B. and J. Jones III, ed. West Sussex: Blackwell Publishing Ltd. 411-423

Spiro, M. (2011). "Cultural Determinism, Cultural Relativism, and the Comparative Study of Psychopathology." Ethos 29(2): 218-234.

TTCGa [Taita Taveta County Government]. (2013). “The First Taita Taveta County Integrated Development Plan: 2013-2017”.

TTCGb [Taita Taveta County Government]. (2013). "Causes and Remedies to the Declining Standards of Education in Taita Taveta County" Taita Taveta Primary School Task Force.

UNDP [United Nations Development Programme]. (2017). "Energy Access". Accessed on April $14^{\text {th }}, 2017$ at: http://www.undp.org/content/undp/en/home/ourwork/climate-and-disasterresilience/sustainable-energy/energy-access.html

Visser, S. and J. Jones III. (2010). "Measurement and Interpretation.” In Research Methods in Geography. Gomez, B. and J. Jones III, ed. 41-59.

Watts, M. (2012 [1983]). Silent Violence: Food, Famine, and Peasantry in Northern Nigeria. London: University of California Press.

Watts, M. (2015). "The Origins of Political Ecology and the Rebirth of Adaptation as a Form of Thought." The Routledge Handbook of Political Ecology. 19-50.

White, C., L. Bank, S. Jones \& M. Mehlwana. (2008). "Restricted Electricity Use Among Poor Urban Households.” Development of Southern Africa 14(3): 413-423 
Willis, K. (2005). Theories and Practices of Development: Routledge Perspectives on Development. New York: Routledge.

Winkler, H., A. Simões, E. Lèbre La Rovere, M. Alam, A. Rahman and S. Mwakanonda. (2011). "Access and Affordability of Electricity in Developing Countries." World Development 39(6): 1037-1050.

World Bank. (2017). "Energy Imports, Net \% Of Energy Use”: The World Bank Group. Accessed April $12^{\text {th }}, 2017$ at: http://data.worldbank.org/indicator/EG.IMP.CONS.ZS?contextual=default\&locations=K $\mathrm{E}$

World Bank. (2016). "Access to Electricity (\% of Population)": The World Bank Group. Accessed November $2^{\text {nd }}, 2016$ at http://data.worldbank.org/indicator/EG.ELC.ACCS.ZS?end=2012\&locations=KE\&start= $2012 \&$ view=map

Zvoleff, A. A. Kocaman, W. Tim Huh and V. Modi. (2009). "The Impact of Geography on Energy Infrastructure Costs.” Energy Policy 37(10): 4066-4078. 


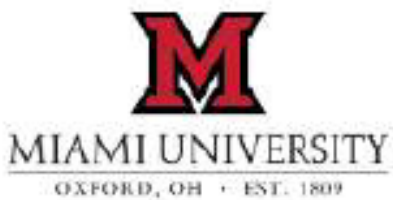

\author{
OFFICE FOR THE ADVANCEMENT OF \\ RESEARCH AND SCHOLARSHIP (OARS) \\ Institutional Review Board for \\ Human Subjects Research \\ 102 Roudebush Hall \\ Oxford, OH 45056 \\ $513-529-3600$
}

Date: $\quad$ May 26, 2016

To: Mr. Christopher Myers, Dr. Kimberly Medley

From: Dr. L. James Smart, Jr., Chair

Institutional Review Board for Human Subjects Research

RE: Political Ecological Critique of Electrification as a Development Initiative for the Kasigau Taita, Kenya

Thank you for submitting the application referenced above to the Institutional Review Board (IRB).

The board has reviewed and approved your proposal through the regulatory Expedited Review procedure.

Your protocol approval number is: $01229 \mathrm{r}$

Approval of this project is in effect until: May 25, 2017

If you complete your project before the date listed above, please send an email message indicating so to humansubjects@miamiOH.edu and we will close your file.

Regulations require periodic review of all ongoing human subjects research projects. If your project will continue beyond the approval date shown above, you will need to submit an Application for Continuing Review and status update for review before the expiration date.

Please submit your next application for continuing review by: April 252017

Should you wish to change your procedures relating to the use of human subjects or personnel having access to the data, you must obtain approval from the IRB prior to instituting any changes.

On behalf of the committee and the University, I thank you for your efforts to conduct your research in compliance with the federal regulations that have been established for the protection of human subjects. Thank you for your attention to this matter, and best wishes for the success of your project. 


\section{To Whom It May Concern:}

My name is Chris Myers. I am a graduate student in the Geography Department at Miami University, located in Oxford, Ohio, USA. The purpose of my study is to gain local perceptions of electricity and how it is being used at Mt. Kasigau, Kenya. Your participation in the research will contribute greatly to documenting local perspectives of electrification near your home. Specifically, I will use this information for my Master's thesis research at Miami University. I hope that we can collaborate on identifying the importance of electricity at Mt. Kasigau.

To achieve this, I would like to ask if I may be able to administer an interview, which consists of asking some (6-8) questions about how you use electricity in your home and community. I will ask about how you use electricity, and how valuable you think electricity is for meeting energy needs in your life. I would like to ask what benefits and challenges the introduction has brought on you. I would ask to have a conversation about how electricity availability has changed at Mt. Kasigau over time. I will record this conversation on paper with a pen, and if it is appropriate, I will use an audio recorder to document the conversations to ensure the accuracy of our conversation, and to refer to it while I am writing my report.

Upon completion of my study, I would like to supply you with any photos taken, as well as a copy of the report and an update of any findings. I would like to say thank you in advance for your invaluable help in this project.

Are you willing to participate in this project, with the knowledge that you have the right to halt participation at any time for any reason?

YES / NO

Sincerely,

Chris Myers

Master's Candidate in Geography

Miami University

Myerscw2@miamioh.edu

For further information, please contact:

Miami University Department of Geography, Tel. 001-513-529-1558

Office for the Advancement of Research and Scholarship - Tel. 011-513-529-3734 